\title{
Significant variations of trace gas composition and aerosol properties at Mt. Cimone during air mass transport from North Africa - contributions from wildfire emissions and mineral dust
}

\author{
P. Cristofanelli ${ }^{1}$, A. Marinoni ${ }^{1}$, J. Arduini ${ }^{2}$, U. Bonafề ${ }^{1}$, F. Calzolari ${ }^{1}$, T. Colombo ${ }^{3}$, S. Decesari ${ }^{1}$, R. Duchi ${ }^{1}$, \\ M. C. Facchini ${ }^{1}$, F. Fierli ${ }^{1}$, E. Finessi ${ }^{1}$, M. Maione ${ }^{2}$, M. Chiari ${ }^{4}$, G. Calzolai ${ }^{4,5}$, P. Messina ${ }^{1,6}$, E. Orlandi ${ }^{1,6}$, \\ F. Roccato ${ }^{1}$, and P. Bonasoni ${ }^{1}$ \\ ${ }^{1}$ ISAC-CNR, Via Gobetti 101, 40129 Bologna, Italy \\ ${ }^{2}$ University of Urbino, Chemistry Institute, Urbino, Italy \\ ${ }^{3}$ Italian Air Force, Centro Nazionale di Meteorologia e Climatologia (CNMCA), Pratica di Mare, Italy \\ ${ }^{4}$ National Institute of Nuclear Physics, Florence, Italy \\ ${ }^{5}$ University of Florence, Physics Department, Florence, Italy \\ ${ }^{6}$ University of Ferrara, Physics Department, Ferrara, Italy
}

Received: 2 February 2009 - Published in Atmos. Chem. Phys. Discuss.: 24 March 2009

Revised: 4 July 2009 - Accepted: 9 July 2009 - Published: 17 July 2009

\begin{abstract}
High levels of trace gas $\left(\mathrm{O}_{3}\right.$ and $\left.\mathrm{CO}\right)$ and aerosol (BC, fine and coarse particle volumes), as well as high scattering coefficient $\left(\sigma_{p}\right)$ values, were recorded at the regional GAW-WMO station of Mt. Cimone (CMN, 2165 m a.s.l., Italy) during the period 26-30 August 2007. Analysis of air-mass circulation, aerosol chemical characterization and trace gas and aerosol enhancement ratios (ERs), showed that high $\mathrm{O}_{3}$ and aerosol levels were likely linked to (i) the transport of anthropogenic pollution from northern Italy, and (ii) the advection of air masses rich in mineral dust and biomass burning (BB) products from North Africa. In particular, during the advection of air masses from North Africa, the $\mathrm{CO}$ and aerosol levels (CO: $175 \mathrm{ppbv}, \mathrm{BC}: 1015 \mathrm{ng} / \mathrm{m}^{3}$, fine particle volume: $3.00 \mu \mathrm{m}^{3} \mathrm{~cm}^{-3}, \sigma_{p}: 84.5 \mathrm{Mm}^{-1}$ ) were even higher than during the pollution event (CO: $138 \mathrm{ppbv}$, BC: $733 \mathrm{ng} / \mathrm{m}^{3}$, fine particles volume: $1.58 \mu \mathrm{m}^{3} \mathrm{~cm}^{-3}, \sigma_{p}$ : $44.9 \mathrm{Mm}^{-1}$ ). Moreover, despite the presence of mineral dust able to affect significantly the $\mathrm{O}_{3}$ concentration, the analysis of ERs showed that the BB event represented an efficient source of fine aerosol particles (e.g. BC), but also of the $\mathrm{O}_{3}$ recorded at $\mathrm{CMN}$. In particular, the calculated $\mathrm{O}_{3} / \mathrm{CO}$ ERs (0.10-0.17 ppbv/ppbv) were in the range of values found in literature for relatively aged ( $2-4$ days) BB plumes and suggested significant photochemical $\mathrm{O}_{3}$ production during
\end{abstract}

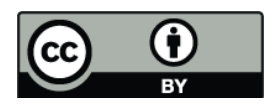

Correspondence to: P. Cristofanelli (p.cristofanelli@isac.cnr.it) the air-mass transport. For fine particles and $\sigma_{p}$, the calculated ERs was higher in the BB plumes than during the anthropogenic pollution events, stressing the importance of the identified BB event as a source of atmospheric aerosol able to affect the atmospheric radiation budget. These results suggest that episodes of mineral dust mobilization and wildfire emissions over North Africa could significantly influence radiative properties (as deduced from $\sigma_{p}$ observations at CMN) and air quality over the Mediterranean basin and northern Italy.

\section{Introduction}

In the troposphere, among the major sources of atmospheric pollutants and climate altering species, an important role is played by biomass burning (BB) events (e.g. Crutzen and Andreae, 1990; Goode at al., 2000; Simmonds et al., 2005). In particular, boreal forest wildfires have a considerable impact on the variability of tropospheric $\mathrm{CO}$ and $\mathrm{O}_{3}$ in the Northern Hemisphere (e.g. Novelli et al., 2003). CO strongly influences the abundance of the $\mathrm{OH}$ radical and initiates several important chemical reactions involving climate altering compounds and chemically active gases (e.g., Seinfeld and Pandis, 1998; Forster et al., 2007). $\mathrm{O}_{3}$ is strongly involved in photochemical reactions (Crutzen et al., 1999; Volz-Thomas et al., 2002) and in determining the oxidation capacity of the

Published by Copernicus Publications on behalf of the European Geosciences Union. 
troposphere (Gauss et al., 2003). Moreover it is a dangerous pollutant (Brunekreef and Holgate, 2002) and an efficient greenhouse gas (Forster et al., 2007). Due to chemical and photo-chemical processes and mixing with air-masses of different origin, the $\mathrm{O}_{3}$ levels in the $\mathrm{BB}$ plumes can strongly vary during the export from the emission regions (Real et al., 2007). Large wildfires can also emit large amounts of aerosol particles (Hsu et al., 1999; Christopher et al., 2000). In particular, the black carbon (BC) produced by boreal wildfires accounts for $10 \%$ of the annual anthropogenic BC emissions in the Northern Hemisphere (Bond et al., 2004). Due to its direct impact on solar and thermal radiation, $\mathrm{BC}$ was recognised as a contributing factor in global warming (Andreae and Gelencsèr, 2006 and references therein). Additionally, BB aerosols are responsible for an indirect radiative forcing by modifying the concentration and size spectrum of cloud droplets (e.g. Lohmann et al., 2000; Forster et al., 2007). Even if important year-to-year variability affect global fire activity and thus wildfire emissions (van der Werf et al., 2006; Le Page et al., 2008), significant increasing trend in fire activity were observed during the recent decades over specific regions like Europe, Africa and US (Mouillot and Fields, 2005; Westerling et al. 2006).

Previous studies have shown that the atmospheric compounds directly emitted by BB or produced by photochemical processes occurring within BB plumes can be transported over long distances, thus affecting both air quality and climate on the regional to global scales (e.g. Val Martin et al., 2006 and references therein). In Europe the Mediterranean basin is affected by large wildfire events, especially during summer. As an example, during the extreme dry and hot summer of 2003, the large forest fires in Spain, Portugal, Greece and Italy, significantly influenced trace gas composition and aerosol properties both in the boundary layer and the free troposphere (Pace et al., 2006; Cristofanelli et al., 2007). However, during summer, large amounts of anthropogenic pollutants from the European boundary layer are also transported towards the Mediterranean basin/South Europe free troposphere (e.g. Henne et al., 2004; Henne et al., 2005a). Moreover, Saharan dust mobilization over African deserts represent a significant natural source of mineral aerosols for the Mediterranean basin, as well as southern and continental Europe (e.g. Papayannis et al., 2008). As mineral dust constitutes a good surface for promoting heterogeneous chemistry (e.g. Zhang et al., 1994) and modifying actinic fluxes (e.g. Dentener and Crutzen, 1993; He and Carmichael, 1999), the background $\mathrm{O}_{3}$ balance in the Mediterranean basin can be strongly affected by the transport of dust particles from North Africa (e.g. Dentener et al., 1996; Bonasoni et al., 2004). Therefore, the Mediterranean basin and South Europe can be strongly impacted both by mineral dust from North Africa and by natural and anthropogenic pollutant emissions, thus confirming this area to be a major crossroad of different air mass transport processes (Lelieveld et al., 2002; Millàn, 2006; Duncan et al., 2008).
During late August 2007, at the GAW-WMO Station of Mt Cimone (Italy), high levels of trace gases $\left(\mathrm{O}_{3}\right.$ and $\left.\mathrm{CO}\right)$ were recorded, together with significant variations in the aerosol properties (equivalent BC contents, particle volume, scattering coefficient, chemical composition). The present paper shows that such variations were probably related to a pollution event over northern Italy, combined with event of mineral dust and BB product transport from North Africa. Since Mt. Cimone is located on the northern Mediterranean basin and south of continental Europe, the observations carried out there can provide useful information for better evaluating the role of different transport processes in modifying the tropospheric background conditions in this crucial area.

\section{Experimental and methodologies}

\subsection{Site and measurement descriptions}

Measurements of surface $\mathrm{O}_{3}$ and $\mathrm{CO}$ concentrations, along with aerosol physical (size distribution, equivalent BC concentration, scattering coefficient) and chemical properties (organic and inorganic composition) were carried out at the regional GAW-WMO Station of Mt. Cimone (CMN; $44^{\circ} 11^{\prime} \mathrm{N}, 10^{\circ} 42^{\prime} \mathrm{E}, 2165 \mathrm{~m}$ a.s.1.). The $\mathrm{CMN}$ measurements are considered representative for the baseline conditions of the Mediterranean free troposphere (Bonasoni et al., 2000; Fischer et al., 2003), even if during the warm months an influence of boundary layer air can be detected due to convective processes and mountain breeze system (Fischer et al., 2003; Van Dingenen, 2005). At CMN, tropospheric $\mathrm{O}_{3}$ measurements have been carried out continuously since 1996 using a UV-photometric analyser (Dasibi 1108). The accuracy and quality of measurements (sampling time: $1 \mathrm{~min}$, combined standard uncertainty less than \pm 2 ppbv in the range $1-100 \mathrm{ppbv}$ ) and sampling procedures are guaranteed within the GAW requirements (WMO, 2002). In particular, the $\mathrm{O}_{3}$ analyser working at CMN was traced back to EMPA (Swiss Federal Laboratories for Materials Testing and Research) SRP\#15 Standard Reference Photometer. The CO concentrations are measured by a GC-RGD set up, consisting of a custom gas chromatograph equipped with a reduction gas detector - Trace Analytical RGD2. The instrument has been running continuously since January 2007. Every $15 \mathrm{~min}$ an air sample is injected into the gas chromatograph for separation, and then analysed for $\mathrm{CO}$ concentration via mercury oxide reduction and detection of mercury vapours by UV absorption. Each sample for analysis is alternated with a calibration sample by means of real air working standards with concentrations representative for ambient air concentration for the Northern Hemispheric troposphere. The working standards were prepared at Max-Planck-Institute for Biogeochemistry in Jena and referenced against the CSIRO/1999 scale. This guarantees a continuous check of the detector calibration 
(Novelli, 1999) with an accuracy higher than $\pm 0.5 \%$ on the recorded $\mathrm{CO}$ concentration values.

Concerning aerosol measurements, particle concentration and size distribution are obtained using an optical particle counter (OPC; Grimm, Particle Size Analyzer Mod. 1.108) in the size range $0.3 \mu \mathrm{m} \leq \mathrm{Dp} \leq 20 \mu \mathrm{m}$. The instrument is based on the quantification of the $90^{\circ}$ scattering of light by aerosol particles. According to the specifications, the reproducibility of the OPC in particle counting is $\pm 2 \%$ (Putaud et al., 2004). Such measurements allow the determination of the fine $(0.3 \mu \mathrm{m} \leq \mathrm{Dp}<1 \mu \mathrm{m})$ and coarse $(1 \mu \mathrm{m} \geq \mathrm{Dp}>20 \mu \mathrm{m})$ aerosol fractions with a $1 \mathrm{~min}$ time resolution. OPC size distribution was used to derive aerosol volume for fine $\left(V_{\text {fine }}\right)$ and coarse $\left(V_{\text {coarse }}\right)$ particles. In particular, large increases in coarse particle volume are usually considered indicative of the presence of mineral dust at this measurement site (Bonasoni et al., 2004; Van Dingenen et al., 2005; Marinoni et al., 2008). At CMN, continuous measurements of equivalent black carbon concentration (BC) is obtained by a multi-angle absorption photometer (MAAP 5012, Thermo Electron Corporation). This instrument measures the absorption coefficient of aerosol deposited on a glass fibre filter tape, with removal of the scattering effect (at different angles) that can interfere with optical absorption measurements. The reduction of light transmission at $670 \mathrm{~nm}$, multiple reflection intensities, and air sample volume are continuously integrated over the sample run period to provide a real time data output (1 min resolution, variable integration time) of $\mathrm{BC}$ concentration (Petzold et al., 2002). Finally, an integrating nephelometer (Ecotech M9003) continuously determines $\sigma_{p}$, i.e. the scattering coefficient of light at $520 \mathrm{~nm}$ due to atmospheric particles.

\subsection{Aerosol chemistry}

Atmospheric aerosols in the $1-10 \mu \mathrm{m}\left(\mathrm{PM}_{1-10}\right)$ and $<1 \mu \mathrm{m}$ $\left(\mathrm{PM}_{1}\right)$ size fractions were collected on quartz-fiber filters using a dichotomous sampler from MSP Corporation (Universal Air Sampler, model 310) at a constant nominal air flow rate of $300 \mathrm{lt} / \mathrm{min}$. Based on the aerosol emission and transport forecast provided by the NAAPS - Navy Aerosol Analysis and Prediction System (Hogan et al., 1991, 1993; http: //www.nrlmry.navy.mil/aerosol_web/) showing an incoming Saharan dust transport episode to North Italy, daily samples were collected from 27 to 30 August 2007. Sampling times varied approximately from 22 to $24 \mathrm{~h}$, starting at around 11 a.m. until approximately the same time on the following day. After sampling, the filters were analyzed for their carbon content and concentration of water-soluble inorganic ions. The coarse $\left(\mathrm{PM}_{1-10}\right)$ aerosol samples also underwent analysis of mineral oxides. The study of the carbonaceous material in both size fractions included the determinations of total carbon (TC) by evolved gas analysis, and of watersoluble organic carbon (WSOC) and carbonate carbon by liquid TOC. Both methods were carried out using a Multi N/C
2100 total organic carbon analyser. The difference between TC and WSOC and carbonate carbon (Matta et al., 2003; Rinaldi et al., 2007) resulted in the water-insoluble carbon (WINC). Water-soluble organic matter (WSOM) and waterinsoluble carbonaceous matter (WINCM) were derived from WSOC and WINC using conversion factors of 1.8 and 1.2, respectively. The WSOM chemical composition of $\mathrm{PM}_{1}$ samples was investigated using HNMR spectroscopy (Decesari et al., 2006), with the aim of determining the concentration of levoglucosan (Schkolnik and Rudich, 2006), a major biomass burning tracer. Briefly, the method is based on direct analysis of WSOM in $\mathrm{D}_{2} \mathrm{O}$ solution with identification and quantification of levoglucosan on the basis of the signal of its anomeric proton at $5.4 \mathrm{ppm}$ of chemical shift. Inorganic ions $\left(\mathrm{NH}_{4}^{+}, \mathrm{Na}^{+}, \mathrm{K}^{+}, \mathrm{Mg}_{2}^{+}, \mathrm{Ca}_{2}^{+}, \mathrm{Cl}^{-}, \mathrm{NO}_{2}^{-}, \mathrm{NO}_{3}^{-}, \mathrm{SO}_{4}^{2-}\right)$ and light organic ions (acetate, formate, oxalate and methansulfonate) concentrations were determined by ion chromatography (IC). Finally, mineral dust elements in the coarse aerosol fraction, including $\mathrm{Mg}, \mathrm{Al}, \mathrm{Ca}, \mathrm{K}, \mathrm{Ti}, \mathrm{Mn}$ and $\mathrm{Fe}$, were simultaneously detected by means of Particle-Induced X-ray Emission (PIXE), while Al was detected by Particle-Induced Gamma-ray Emission (PIGE) with $3.06 \mathrm{MeV}$ protons using the external beam facility at the $3 \mathrm{MV}$ Tandetron accelerator of LABEC laboratory of INFN in Florence (Calzolai et al. 2006). Quantitative concentrations were deduced by a sensitivity curve obtained by analyzing thin reference standards from Micromatter of known elemental composition (uncertainty $\pm 5 \%$ ), at the same experimental conditions as for real samples. The mass of total mineral material was reconstructed from the elemental composition using the following equation:

$$
\begin{aligned}
& \text { Crustal matter }=1.12 \times[1.658 \times \mathrm{Mg}+1.889 \times \mathrm{Al} \\
& +2.139 \times \mathrm{Si}+1.204 \times \mathrm{K}+1.399 \times \mathrm{Ca}+1.668 \times \mathrm{Ti} \\
& +1.582 \times \mathrm{Mn}+(0.5 \times 1.286+0.5 \times 1.429) \times \mathrm{Fe}]
\end{aligned}
$$

where the concentrations of $\mathrm{Ca}, \mathrm{Mg}$ and $\mathrm{K}$ were those of the insoluble fractions (=total element concentrations minus the amount determined by ion chromatography). The Si concentration, which cannot be determined in aerosol samples collected on quartz-fiber filters, was derived from that of $\mathrm{Al}$, using an average factor $\mathrm{Si} / \mathrm{Al}=2.31$, typical for the dust outbreaks at CMN (Marenco et al., 2006).

\subsection{BOLAM model and back-trajectory calculations}

In order to determine the origin of air masses reaching CMN, 3-D air mass back-trajectories (with 1 hour resolution along their path) were calculated every one hour using the BOLAM (BOlogna Limited Area Model) mesoscale meteorological model (Buzzi and Foschini, 2000). BOLAM is a meteorological model based on the primitive equations in the hydrostatic approximation. The 3-D variables are defined on vertical hybrid coordinates and are distributed on a nonuniformly spaced Lorenz grid. The horizontal discretization 
is based on geographical coordinates with latitudinal rotation on an Arakawa C-grid. The initial and lateral boundary conditions were supplied from ECMWF analyses at $0.5^{\circ} \times 0.5^{\circ}$ resolution, distributed by the MAP (Mesoscale Alpine Programme) Data Centre. Gridded data are available every $6 \mathrm{~h}$ on 91 vertical hybrid levels of the ECMWF. The simulation, run from 24 August 00:00 UTC to 31 August 00:00 UTC, covers an area centred over the western Mediterranean basin $\left(251 \times 231\right.$ grid points), with $0.1^{\circ} \times 0.1^{\circ}$ horizontal resolution and 40 vertical hybrid levels extending from the ground level (1224 ma.s.l. for the location of CMN) to the top of the atmosphere defined as $0.1 \mathrm{hPa}$.

Clusters of back-trajectories were calculated using the approach proposed by Gheusi and Stein (2002) and applied by Fierli et al. (2008). The air parcel position is transported as a passive tracer, experiencing advection, transport by subgrid turbulence, convection and vertical diffusion. Compared to the usual Lagrangian trajectory calculations, this technique has the advantage of avoiding any time or spatial interpolation of the model wind field, because the transport processes are calculated at every time step and at every grid point. Moreover, since the subgrid transport processes are taken into account, the motions captured by the Lagrangian tracers correspond exactly to the model dynamics. Gheusi and Stein (2002) have demonstrated that the Lagrangian evolution can be studied on a qualitative basis for relatively large trajectory clusters. In the present paper, this method was applied off-line and a total of 12 clusters (one every $6 \mathrm{~h}$ ) was calculated during the period 28 August 2007 06:00 UTC-31 August 2007 00:00 UTC. Each single trajectory (starting at a fixed time and extending backward to 24 August 2007 00:00 UTC) originated from the model grid points included in a box centred over the $\mathrm{CMN}$ position (longitude: $9.4^{\circ} \mathrm{E}-11.4^{\circ} \mathrm{E}$, latitude: $44.0^{\circ} \mathrm{N}-44.5^{\circ} \mathrm{N}$ ) and ranging between $750 \mathrm{hPa}$ and the ground height, thus leading to the advection of about 260 parcels.

\subsection{Enhancement ratios (ER)}

For the purpose of attaining a better characterisation of the pollution and $\mathrm{BB}$ products affecting $\mathrm{CMN}$, the enhancement ratios (ER) for aerosol and $\mathrm{O}_{3}$ were calculated. According to Andreae and Merlet (2001), the excess of a trace species " $\mathrm{X}$ " normalized by the increase of CO concentrations can provide an estimation of the species " $\mathrm{X}$ " production by combustion processes. $\mathrm{CO}$ is considered the reference species because it is one of the principal compounds emitted by combustion (Andreae and Merlet, 2001) and has a relatively long lifetime in the troposphere (Novelli et al., 1992). Usually, two methods are used to evaluate ERs. The so-called "enhancement technique" (e.g. Pfister et al., 2006 and references therein) determines ERs by evaluating $\mathrm{CO}$ and " $\mathrm{X}$ " species mixing ratio increases with respect to "background" conditions. The so-called "scatter-technique" determines ERs by calculating the slope of the linear fit be- tween "X" species and CO concentrations (e.g. Parrish et al., 1998). As each one of these methods has specific strengths and weaknesses (see for more details Bertische and Jaffe, 2005 or Pfister et al., 2006), in this work both were applied to anthropogenic pollution and BB tracers (i.e. BC, fine particle volumes, $\sigma_{p}$ and $\mathrm{O}_{3}$ ). In particular, for the "enhancement technique" analysis the background levels of trace gas and aerosol were evaluated by analysing the 7-day FLEXTRA 3-D back-trajectories (Stohl et al., 1995), which were calculated every $6 \mathrm{~h}$ for the CMN endpoint, based on the ECMWF wind field $\left(1^{\circ} \times 1^{\circ}\right.$ geographical resolution). As shown in previous works (e.g. Wotawa et al., 2000; Fischer et al., 2003), in spite of the coarse meteorological data resolution driving FLEXTRA, the model revealed remarkable skill in simulating the transport of air masses towards mountain sites. In particular, to exclude air masses possibly influenced by wildfire emissions and experiencing direct mixing within the PBL, it was decided to select the back-trajectories that travelled above $2000 \mathrm{~m}$ a.s.l before reaching CMN and that originated over a pristine area (i.e. the North Atlantic region). This led to a very restrictive definition of trace gas and aerosol background levels at CMN for the summer 2007 (Table 1). In fact, by applying this filter, only $5 \%$ of the 368 calculated back-trajectories were selected.

\section{Results}

\subsection{Data overview}

Time series of $30 \mathrm{~min}$ averages for $\mathrm{O}_{3}, \mathrm{CO}, \mathrm{BC}, V_{\text {fine }}$ and $V_{\text {coarse }}$ as well as $\sigma_{p}$, are shown in Fig. 1. During the period 26-30 August 2007, high average levels of trace gases $\left(\mathrm{O}_{3}\right.$ : $67 \pm 10 \mathrm{ppbv} ; \mathrm{CO}: 129 \pm 25 \mathrm{ppbv}$; mean $\left.\pm 1-\sigma\right)$ and aerosols (BC: $615 \pm 223 \mathrm{ng} / \mathrm{m}^{3} ; V_{\text {fine }}: 1.93 \pm 0.99 \mu \mathrm{m}^{3} \mathrm{~cm}^{-3}$; $V_{\text {coarse }}: 13.11 \pm 6.25 \mu \mathrm{m}^{3} \mathrm{~cm}^{-3} ; \sigma_{p}: 46.6 \pm 14.7 \mathrm{Mm}^{-1}$ ) were recorded. They are presented against average values for the whole of summer 2007 in Table 1. In particular, as shown by the analysis of box-and-whiskers plots (Fig. 2), the concentrations of $\mathrm{CO}, \mathrm{BC}, V_{\text {fine }}$ and $V_{\text {coarse }}$ particles, as well as $\sigma_{p}$ values, were characterised by a median exceeding the 75th percentile of the summer 2007. During the same period, the $\mathrm{O}_{3}$ distribution was also characterised by an marked increase of the upper quartiles $(+5.6 \mathrm{ppbv}$ for the 75 th percentile; +6.2 ppbv or the 95 th percentile).

\subsection{Meteorology and air mass circulation over the Mediterranean basin}

The BOLAM simulation for 24 August 2007 (here not shown) highlighted that the passage of a trough over West Europe favoured the transport of air masses from North Africa to the central Mediterranean and Italy. From 25 to 28 August 2007 the low tropospheric circulation over the central Mediterranean basin was instead determined by a highpressure ridge centred over Sardinia, favouring the transport 
Table 1. Comparison of $\mathrm{O}_{3}, \mathrm{CO}, \mathrm{BC}$, fine and coarse particle volumes, and total scattering coefficient $\left(\sigma_{p}\right) 30$ min values during the pollution event over northern Italy, with observations impacted by BB, with all observations during summer 2007 (JJA), and with observations carried out during clean background condition. $\sigma$ and $\mathrm{N}$ indicate the standard deviation and the number of data, respectively.

\begin{tabular}{|c|c|c|c|c|c|c|c|c|c|}
\hline \multirow[b]{2}{*}{ Parameter } & \multicolumn{2}{|c|}{ Summer 2007} & \multicolumn{2}{|c|}{ Background Selection } & \multicolumn{2}{|c|}{ North Italy Pollution } & \multicolumn{2}{|c|}{ Biomass Burning } & \multirow{2}{*}{$\begin{array}{l}\text { Summer 2007: } \\
\text { data availability }\end{array}$} \\
\hline & Min-Max & Mean $(\sigma ; \mathrm{N})$ & Min-Max & Mean $(\sigma ; \mathrm{N})$ & Min-Max & Mean $(\sigma ; \mathrm{N})$ & Min-Max & Mean $(\sigma ; \mathrm{N})$ & \\
\hline $\mathrm{O}_{3}$ (ppbv) & $30-126$ & $64(12 ; 4310)$ & $42-79$ & $61(8 ; 46)$ & $53-111$ & $77(15 ; 41)$ & $60-77$ & $70(5 ; 74)$ & $88 \%$ \\
\hline $\mathrm{CO}$ (ppbv) & $57-244$ & $107(19 ; 4251)$ & $74-134$ & $99(11,45)$ & $94-184$ & $138(21 ; 41)$ & $144-243$ & $175(18 ; 74)$ & $91 \%$ \\
\hline $\mathrm{BC}\left(\mathrm{ng} / \mathrm{m}^{3}\right)$ & $<6-1411$ & $273(244 ; 4069)$ & $<11-554$ & $181(119,38)$ & $234-1680$ & $733(334,41)$ & $521-1483$ & $1015(194 ; 74)$ & $81 \%$ \\
\hline$V_{\text {fine }}\left(\mu \mathrm{m}^{3} \mathrm{~cm}^{-3}\right)$ & $<10^{-3}-5.80$ & $0.82(0.80 ; 3832)$ & $0.05-1.83$ & $0.63(0.48 ; 39)$ & $0.83-3.16$ & $1.58(0.54 ; 41)$ & $0.27-4.59$ & $3.00(0.80 ; 73)$ & $72 \%$ \\
\hline$V_{\text {coarse }}\left(\mu \mathrm{m}^{3} \mathrm{~cm}^{-3}\right)$ & $<10^{-3}-46.16$ & $2.53(4.58 ; 3832)$ & $0.09-9.98$ & $2.14(2.49 ; 39)$ & $3.19-9.09$ & $9.09(4.77 ; 41)$ & $0.05-31.57$ & $15.54(6.08 ; 73)$ & $72 \%$ \\
\hline$\sigma_{p}\left(\mathrm{Mm}^{-1}\right)$ & $2.0-137.7$ & $27.0(21.58 ; 4083)$ & $5.9-64.7$ & $24.9(16.0 ; 37)$ & $22.1-79.4$ & $44.9(14.4 ; 41)$ & $19.3-137.7$ & $84.5(18.6 ; 72)$ & $92 \%$ \\
\hline
\end{tabular}

of air masses from North Africa towards northern Italy, as shown by the BOLAM analyses (Fig. 3a). Subsequently the high-pressure system weakened and moved southward over the Algerian coast. From 28 August 2007 a low-pressure trough affected Western Europe (Fig. 3b), again favouring air mass transport from North Africa toward northern and central Italy. The end of air mass advection from North Africa, around 31 August 2007, was related to the eastward displacement of the low-pressure system (not shown), which induced a westerly flow over northern Italy and CMN.

These conditions favoured the transport of mineral dust from the Sahara, as confirmed by the high $V_{\text {coarse }}\left(>10.0 \mu \mathrm{m}^{3} \mathrm{~cm}^{-3}\right)$ recorded at CMN (Fig. 1) from 25 to 30 August 2007. Although OPC measurements were not available for the onset of the transport event, the NAAPS simulations (not shown) indicated that dust mobilized over Algeria, Morocco and Mauritania reached Southern Europe and Northern Italy, starting from 23 August 2007. The mobilization of mineral dust over Sahara desert was confirmed also by the OMI (Ozone Monitoring Instrument) measurements, showing high values of Aerosol Index over this area (Fig. 4).

The same high pressure area which favoured the transport of mineral dust from North Africa to northern Italy, also promoted very dry and hot meteorological conditions over South Europe and North Africa (WMO, 2008). In particular, from 24 to 28 August 2007, the geopotential height at the $500 \mathrm{hPa}$ surface showed very high values (from 592 to 600 dam) over a large area, extending from North Africa to Eastern Europe, with surface temperature higher than $40^{\circ} \mathrm{C}$ over southern Italy, Algeria and Tunisia. Over the Po Basin (northern Italy), these meteorological conditions favoured the onset of photochemical smog episodes. In fact, data recorded by the Regional Agency for Environmental Protection of EmiliaRomagna (ARPA-ER) showed increasing daily $\mathrm{O}_{3}$ maxima from 25 to 28 August 2007, when the population information threshold (i.e. $180 \mu \mathrm{g} / \mathrm{m}^{3}$ ) was exceeded.

The hot and dry meteorological conditions associated with the extensive high pressure system also favoured the onset of several wildfires over Greece, southern Italy and North

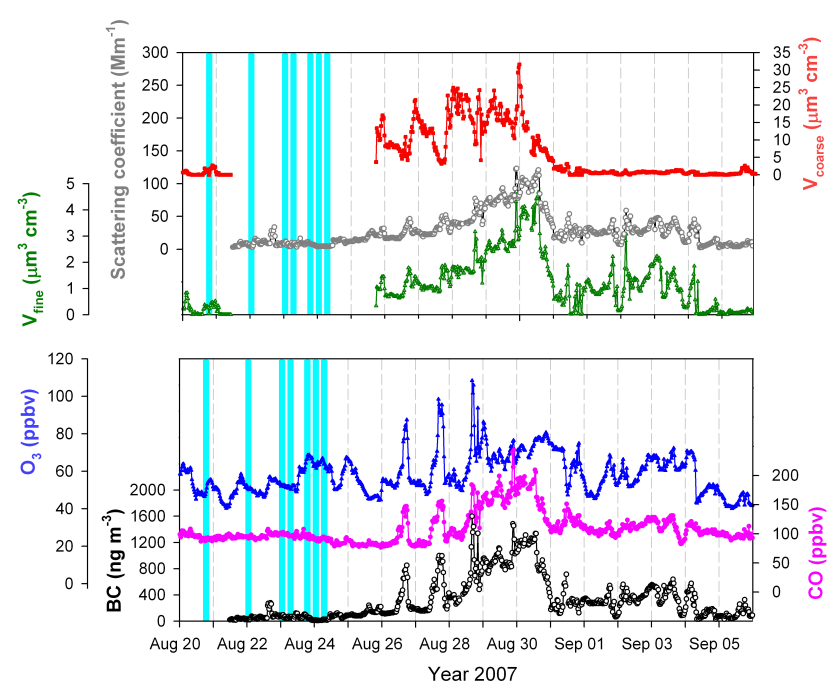

Fig. 1. Mt. Cimone: 20 August-5 September 2007. Upper plate: $30 \mathrm{~min}$ averaged values for $V_{\text {coarse }}\left(\right.$ red), $V_{\text {fine }}$ (green) and $\sigma_{p}$ (grey). Bottom plate: 30 min averaged concentrations of $\mathrm{O}_{3}$ (blue), $\mathrm{BC}$ (black) and CO concentrations (purple). The cyan bars indicate the periods characterised by summer background conditions as defined in the Sect. 2.4.

Africa (Kaiser et al., 2008; Turquety et al., 2008). In particular, diffuse fire events affected the Atlas region. According to news reports, several people died, dozens of families had to evacuate their homes, and the number of people seeking medical attention for respiratory and allergy problems dramatically increased as a result of the fires. As evidenced by the image captured by the Moderate Resolution Imaging Spectroradiometer (MODIS) on board NASA's Aqua satellite (Fig. 5), a thick haze of brownish-grey smoke was emitted by these fires and transported across the Mediterranean Sea. As deduced by the analysis of the daily total number of MODIS hot spot fires obtained according to the method reported by Justice et al. (2002) and Giglio et al. (2003), over North African coastlines (defined as the geographical box: $0^{\circ} \mathrm{E}<$ Lon. $<10^{\circ} \mathrm{E} ; 35^{\circ} \mathrm{N}<$ Lat. $<37^{\circ} \mathrm{N}$ ) wildfires started on 25 August 2007 with a peak from 28 to 30 August 2007 (Fig. 4). 

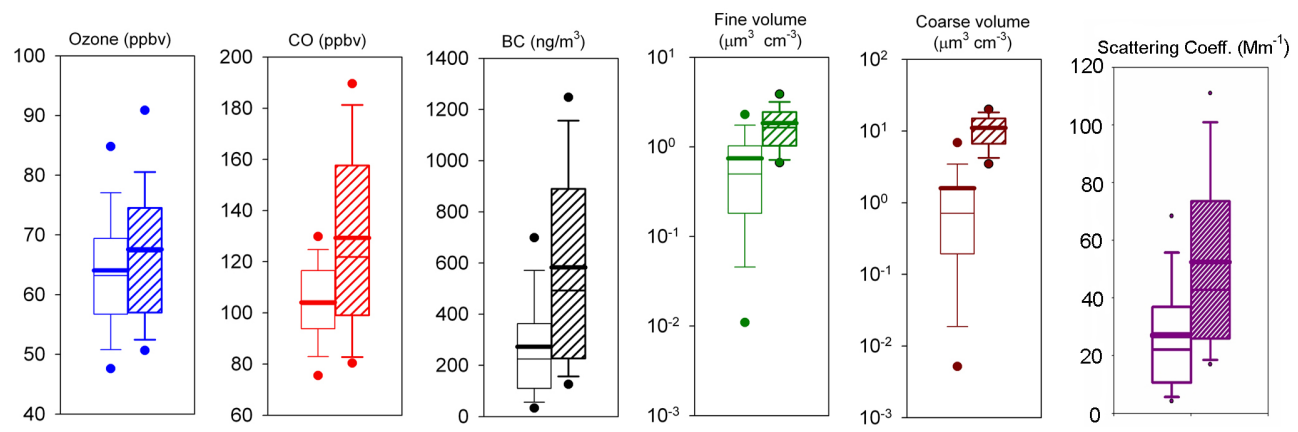

Fig. 2. Box-and-whiskers plot of 30 min averaged values for $\mathrm{O}_{3}$ (blue), $\mathrm{CO}$ (red), $\mathrm{BC}$ (black), $V_{\text {fine }}$ (green), $V_{\text {coarse }}$ (brown) and $\sigma_{p}$ (purple) at Mt. Cimone in June-August 2007 (on the left) and for 26-30 August 2007 (on the right, bold). The box and whiskers denote the 10th, 25th, 50th, 75th and 90th percentiles, the dots represent the 5th and 95th percentiles and the bold lines the average values.
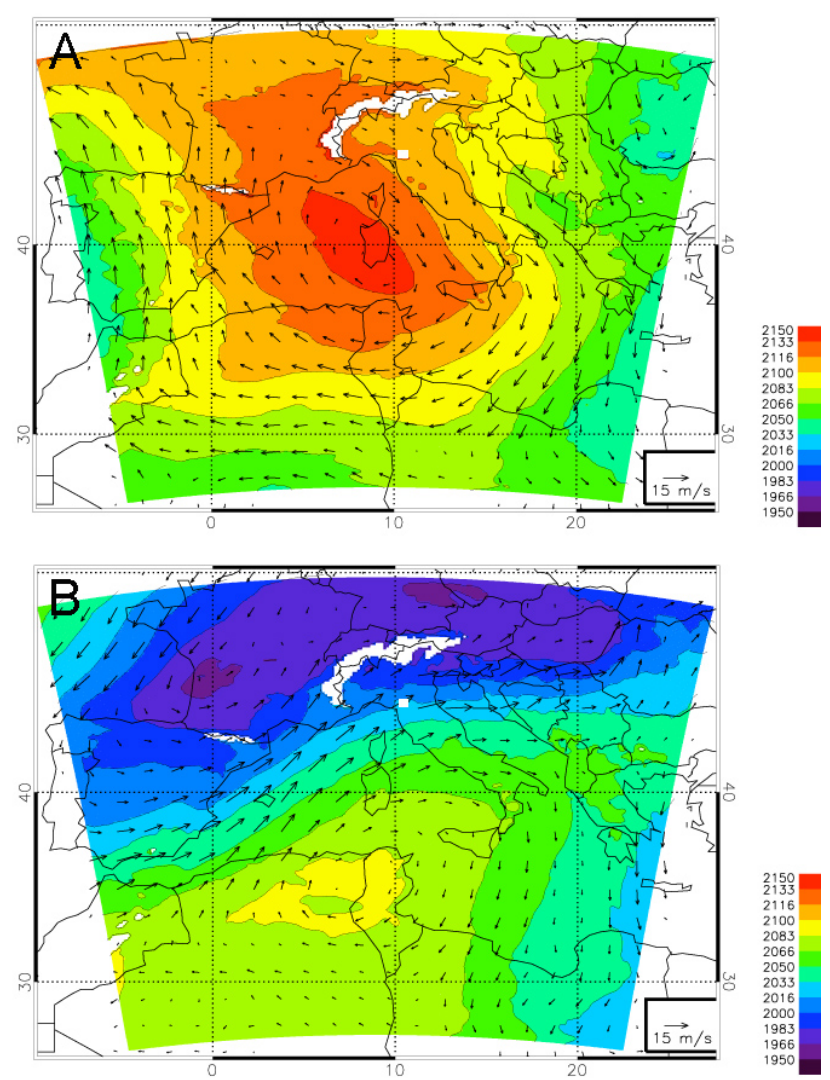

Fig. 3. Geopotential height (expressed in meters, coloured scale) and wind vectors at $800 \mathrm{hPa}$, deduced by BOLAM analysis on 26 August 2007 12:00 UTC (A) and 29 August 2007 12:00 UTC (B). The white square denotes the CMN location.

\subsection{6-28 August 2007: pollution event over northern Italy}

As shown by the analysis of $1 \mathrm{~min}$ average values, during 26-28 August 2007, three consecutive episodes of elevated trace gas and fine aerosol levels were recorded at

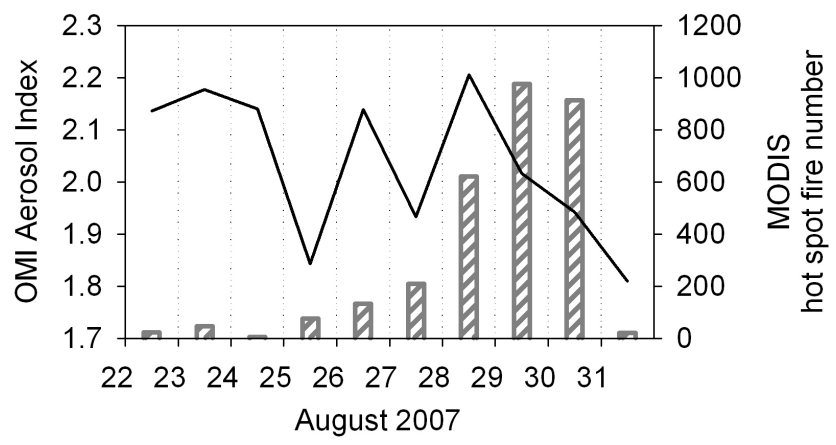

Fig. 4. Daily values of OMI Aerosol Index averaged over the Sahara desert (continuous line, left y-axis) and daily number of MODIS hot spot fire (bars, right $\mathrm{y}$-axis) detected over the North African coastlines (Lat: $0^{\circ} \mathrm{E}-10^{\circ} \mathrm{E}$; Lon: $37^{\circ} \mathrm{N}-35^{\circ} \mathrm{N}$ ) during August 2007 (data courtesy by NASA/GSFC and University of Maryland, Goddard Earth Sciences Data and Information Services Center and KNMI).

CMN (Fig. 6). Compared to the average conditions at $\mathrm{CMN}$ for summer 2007, the levels of $\mathrm{O}_{3}, \mathrm{CO}, \mathrm{BC}, V_{\text {fine }}$ and $\sigma_{p}$, appeared extremely enhanced on these days (Table 1). In particular, the $\mathrm{O}_{3}$ peak (116 ppbv) recorded during the late afternoon/evening on 28 August 2007 was the highest $\mathrm{O}_{3}$ concentration recorded at CMN during the whole of 2007. All the above pollutants showed similar strong diurnal cycles peaking in the late afternoon/evening, suggesting common driving processes and sources. As also shown in Fig. 6, the periods characterised by enhanced pollution levels were also characterised by rather low wind speeds (median value: $3.4 \mathrm{~m} / \mathrm{s}$ ), scattered wind directions (mostly ranging from SW to NE with $85 \%$ of occurrences from the North sector), and increased relative humidity (up to 70-80\%). Even if no measurements of vertical wind velocity were performed at CMN, it is likely that daytime valley breezes and convective processes transported humid and polluted air masses from the planetary boundary layer (PBL) to the measurement site. In fact, during typical anticyclonic conditions, thermal wind 


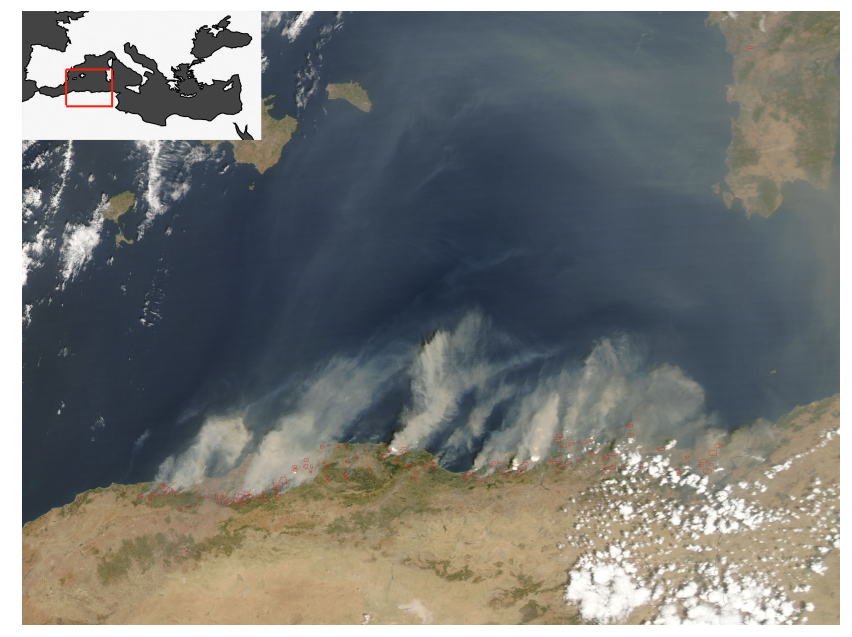

Fig. 5. True colour image detected over North Africa by MODIS (Moderate Resolution Imaging Spectroradiometer) on NASA's Aqua satellite on 29 August 2007 (courtesy of http:// earthobservatory.nasa.gov/).

systems are often observed in mountain areas (Vergeiner and Dreiseitl, 1987; Zaveri et al., 1995; Henne et al., 2005b). Together with entrainment processes related to diurnal PBL growth (Beck et al., 1997; Tressol et al., 2008) and topographic venting (Henne et al., 2004), such wind systems can efficiently contribute to the export of pollutants to the free troposphere during daytime as observed at alpine stations (Baltensperger et al., 1997; Scheel et al., 1997; Carnuth et al., 2002; Schuepbach et al., 2001; Zellweger et al., 2000) and at CMN as well (Fischer et al., 2003; van Dingenen et al., 2005).

The presence of air masses transported from the PBL is also supported by the analysis of coarse particle variations (Fig. 6) which at CMN are greatly influenced by Saharan dust transport events (Marinoni et al., 2008). In fact, on 26-28 August 2007, the $V_{\text {coarse }}$ showed a diurnal cycle with high values during night-time (up to $36.00 \mu \mathrm{m}^{3} \mathrm{~cm}^{-3}$ ) and lower values (below $2.60 \mu \mathrm{m}^{3} \mathrm{~cm}^{-3}$ ) during day-time, when the highest values of pollutant tracers $\left(\mathrm{O}_{3}, \mathrm{CO}, \mathrm{BC}, V_{\text {fine }}\right.$, $\left.\sigma_{p}\right)$ were recorded. This indicated that during night-time, when high wind speeds $(>8.0 \mathrm{~m} / \mathrm{s})$ were recorded, the measurement site was probably affected by air masses originating over North African deserts. Previous investigations (Bonasoni et al., 2004; Bauer et al., 2004) showed that when mineral dust affected $\mathrm{CMN}, \mathrm{O}_{3}$ decreases were recorded due to the interaction of dust particles with solar radiation, and heterogeneous chemical processes. This might also be the case of night-time (00:00-05:00 UTC+1) periods from 26 to 28 August 2007, when average $\mathrm{O}_{3}$ levels ( $54 \pm 2$ ppbv) were significantly (at the $95 \%$ confidence level) lower than for the summer $2007(-16 \%)$ and summer 2007 night-time $(-13 \%)$ average values. During day-time and late evening, on the other hand, the local/regional breeze circulation (as also sug-
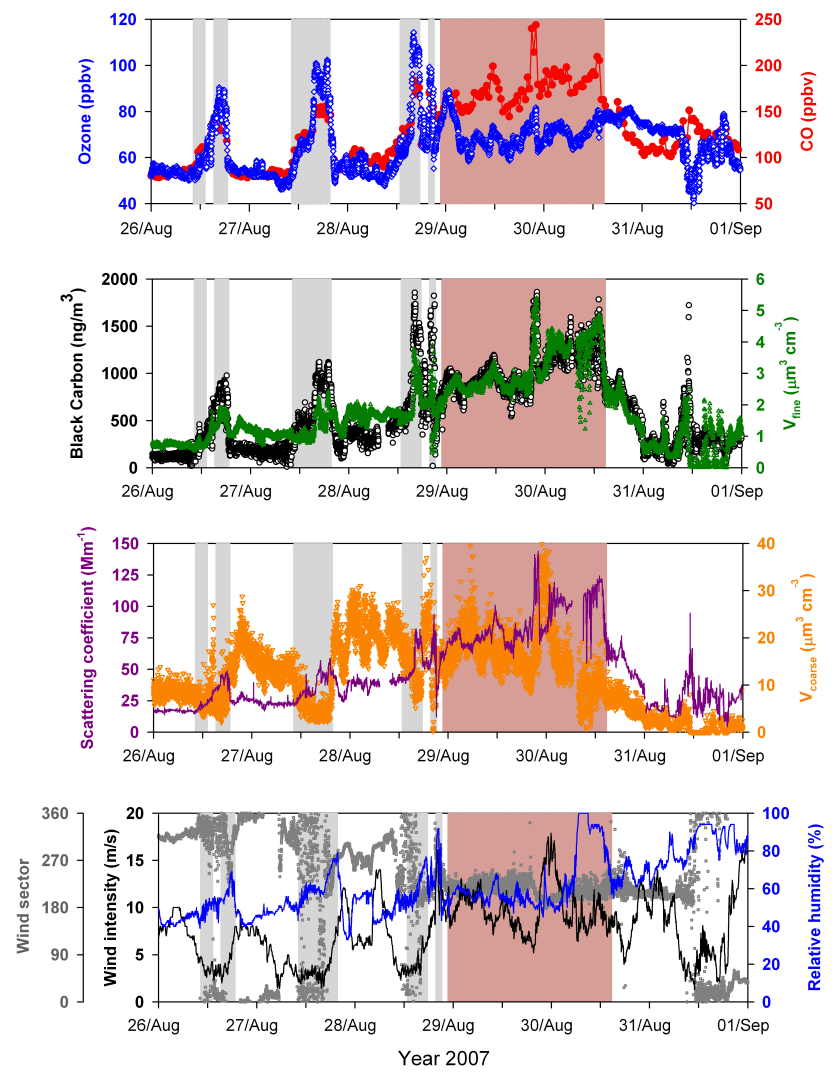

Fig. 6. Time series of 1 min $\mathrm{O}_{3}$ and $\mathrm{CO}$ (blue and red dots, plate (a), BC and $V_{\text {fine }}$ (black and green dots, plate (b), $V_{\text {coarse }}$ and $\sigma_{p}$ (orange dots and purple line, plate (c), wind speed, direction and relative humidity (black line, grey dots and blue line, plate (d) during 26-31 August 2007 at CMN. Grey bars denote the anthropogenic pollution event, red bar denote the BB event.

gested by the light wind speed) transported air masses rich in anthropogenic pollutants and poor in mineral dust from the PBL to the measurement site and possibly to the free troposphere.

In order to analyse better the processes giving rise to such high aerosol and $\mathrm{O}_{3}$ levels, their ERs in respect to $\mathrm{CO}$ were calculated. For each day, periods characterised by $\mathrm{CO}$ values above night-time levels and significant (at the 2- $\sigma$ level) decreases of coarse particle concentrations, were considered (grey bars on Fig. 6). The ERs obtained by applying the "enhancement" and the "scatter" techniques (see Sect. 2.4) are shown in Table 2, while the scatterplots with their linear fits are reported in Fig. 7. For $\sigma_{p}$ and $\mathrm{O}_{3}$, the ERs calculated by the "scatterplot" technique method are higher than those calculated with the "enhancement" method, thus indicating the large uncertainties associated with the ER calculation (Pfister et al., 2006; Real et al., 2007). However, the strong correlations (Fig. 7) between $\mathrm{CO}$ and $\mathrm{BC}\left(R^{2}=0.89\right), V_{\text {fine }}\left(R^{2}=0.66\right), \sigma_{p}\left(R^{2}=0.78\right)$ and $\mathrm{O}_{3}\left(R^{2}=0.89\right)$ suggested the possibility that strong transport 
Table 2. Comparison of $\mathrm{BC}(\Delta \mathrm{BC} / \Delta \mathrm{CO})$, fine particle volume $\left(\Delta V_{\text {fine }} / \Delta \mathrm{CO}\right), \sigma_{p}\left(\Delta \sigma_{p} / \Delta \mathrm{CO}\right)$ and $\mathrm{O}_{3}\left(\Delta \mathrm{O}_{3} / \Delta \mathrm{CO}\right)$ enhancement ratios (ER) with respect to $\mathrm{CO}$ concentrations for the anthropogenic pollution event and the North African BB event. ERs obtained by "enhancement" and "scatter" techniques are both reported.

\begin{tabular}{lllll}
\hline \multirow{2}{*}{ Enhancement Ratios } & \multicolumn{2}{c}{ Anthropogenic Pollution } & \multicolumn{2}{c}{ Biomass Burning } \\
\cline { 2 - 5 } & Enhancement technique & Scatter techniques & Enhancement technique & Scatter techniques \\
\hline$\Delta \mathrm{BC} / \Delta \mathrm{CO}\left(\mathrm{ng} \mathrm{m}^{-3} / \mathrm{ppbv}\right)$ & $14.00 \pm 3.94$ & $14.09 \pm 0.93$ & $10.40 \pm 0.26$ & $8.59 \pm 0.57$ \\
$\Delta V_{\mathrm{fine}} / \Delta \mathrm{CO}\left(\left(\mu \mathrm{m}^{3} \mathrm{~cm}^{-3}\right) / \mathrm{ppbv}\right)$ & $0.024 \pm 0.005$ & $0.020 \pm 0.002$ & $0.030 \pm 0.002$ & $0.026 \pm 0.003$ \\
$\Delta \sigma_{p} / \Delta \mathrm{CO}(\mathrm{Mm}-1 / \mathrm{ppbv})$ & $0.49 \pm 0.06$ & $0.58 \pm 0.02$ & $0.77 \pm 0.09$ & $0.74 \pm 0.04$ \\
$\Delta \mathrm{O}_{3} / \Delta \mathrm{CO}(\mathrm{ppbv} / \mathrm{ppbv})$ & $0.44 \pm 0.06$ & $0.66 \pm 0.04$ & $0.10 \pm 0.04$ & $0.17 \pm 0.03$ \\
\hline
\end{tabular}
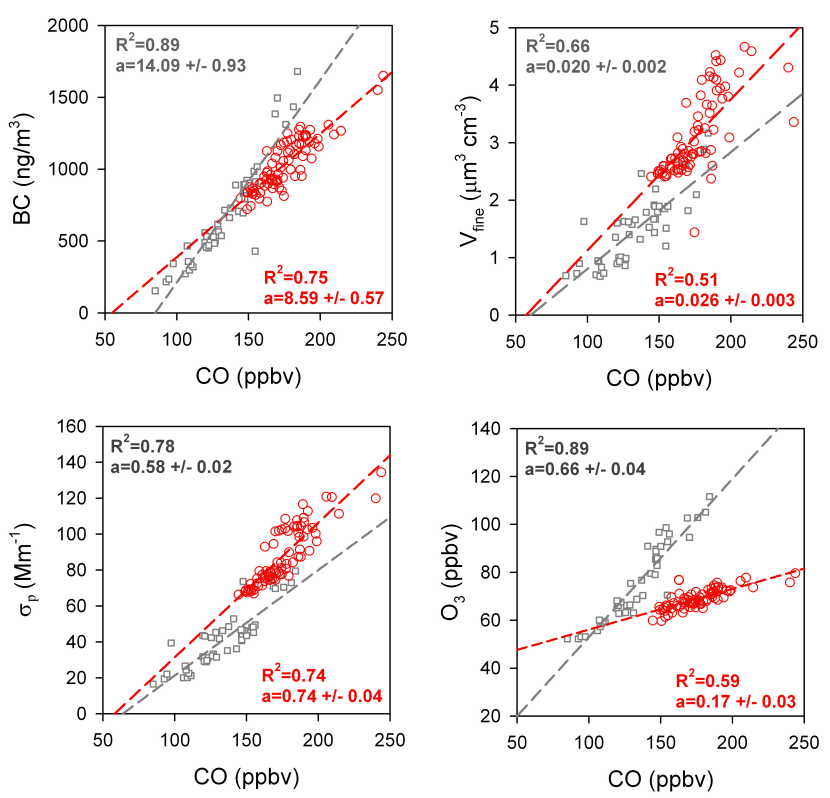

Fig. 7. Relationship between $\mathrm{CO}$ and $\mathrm{BC}, V_{\text {fine }}, \sigma_{p}$ and $\mathrm{O}_{3}$ for the anthropogenic pollution (grey) and the $\mathrm{BB}$ events (red). Linear interpolations together with their fitting parameters (linear correlation coefficient " $R$ " " and the slope "a") are also reported basing on 30 min data.

of pollutants on regional scale could have affected the measurement site (Chen et al., 2001), a hypothesis that is further supported by the high ERs obtained for BC/CO (about $11 \times 10^{-3}$, expressed as $\mu \mathrm{g} / \mathrm{m}^{3}$ BC versus $\mu \mathrm{g} / \mathrm{m}^{3} \mathrm{CO}$ ). Such values are more than double those reported at the baseline station of Mace Head for a long-range pollution event (about $4.0 \mathrm{ng} \mathrm{m}^{-3} / \mathrm{ppbv}$, Jennings et al., 1996), although more in line with those observed in highly populated, industrialized areas (e.g., $6.7 \times 10^{-3} \mu \mathrm{g} \mathrm{m}^{-3} / \mu \mathrm{g} \mathrm{m}^{-3}$, Chen et al., 2001; $8.05 \times 10^{-3} \mu \mathrm{g} \mathrm{m}^{-3} / \mu \mathrm{g} \mathrm{m}^{-3}$, Li et al., 2006). The ERs observed for $V_{\text {fine }}$ and $\sigma_{p}$ (Table 2) are in the upper range of, or higher than those obtained for "anthropogenic" pollution products in previous studies. In fact, Price et al. (2004) and Weiss-Penzias et al. (2006) recorded $\sigma_{p} / \mathrm{CO}$ ratios of $0.5 \mathrm{Mm}^{-1} / \mathrm{ppbv}$ and $0.44 \mathrm{Mm}^{-1} / \mathrm{ppbv}$ within Asian pollution plumes detected over the eastern North Pacific and at Mt. Bachelor (Oregon, USA, $2763 \mathrm{~m}$ a.s.1.), respectively. Please note that considering the number of fine particles instead of $V_{\text {fine }}$, ERs of $(0.60 \pm 0.08) \mathrm{cm}^{-3} / \mathrm{ppbv}$ and $(0.82 \pm 0.06) \mathrm{cm}^{-3} / \mathrm{ppbv}$ were obtained for "enhancement" and the "scatter" technique $\left(R^{2}=0.82\right)$, respectively. However, bearing in mind that OPC only detects particles with radii greater that $0.3 \mu \mathrm{m}$, great caution should be deserved in considering these results as representative of submicron particle number.

The ERs obtained for $\mathrm{O}_{3}$ (Table 2) were also higher than values usually recorded in middle and upper troposphere (e.g. Fischer et al., 2002; Wang et al., 2006), or at remote sites in the moderately polluted boundary layer air of North America (Chin et al., 1994), Canadian Atlantic coastlines (Parrish et al., 1993) and central Atlantic Ocean during summer (Parrish et al., 1998). The retrieved $\mathrm{O}_{3}$ ERs were also higher than the $\mathrm{O}_{3} / \mathrm{CO}$ slope $(0.25 \mathrm{ppbv} / \mathrm{ppbv})$ observed by Fischer et al. (2003) at CMN during June 2000. This further stressed the strong influence played by photochemical $\mathrm{O}_{3}$ production associated with reactive carbon (CO and hydrocarbon) emissions (Fishman et al., 1980) during the August 2007 episode.

\subsection{9-30 August 2007: mineral dust and BB products from North Africa}

Starting in the evening of 28 August 2007, high trace gas and aerosol concentrations were continuously observed at CMN for about $36 \mathrm{~h}$ (until midday on 30 August 2007, see Fig. 1). $30 \mathrm{~min}$ averages of $\mathrm{O}_{3}, \mathrm{CO}, \mathrm{BC}, V_{\text {fine }}$ and $\sigma_{p}$ peaked at $77 \mathrm{ppbv}, 243 \mathrm{ppbv}, 1483 \mathrm{ng} \mathrm{m}^{-3}, 4.59 \mu \mathrm{m}^{3} \mathrm{~cm}^{-3}$ and $137.7 \mathrm{Mm}^{-1}$, at 23:00 UTC+1 on the 29 August 2007. Besides being much higher than average summer 2007 levels, the trace gas and aerosol concentrations were comparable with those recorded during the pollution event (Table 1). Moreover, high $V_{\text {coarse }}$ were recorded at the measurement site (average value: $15.54 \pm 6.08 \mu \mathrm{m}^{3} \mathrm{~cm}^{-3}$ ), indicating the presence of mineral dust. In fact, the 3-D backtrajectory ensembles calculated by BOLAM (Fig. 8) showed 


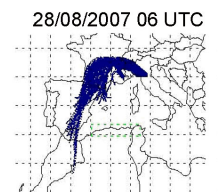

29/08/2007 06 UTC

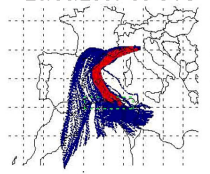

30/08/2007 06 UTC

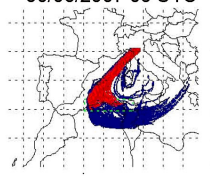

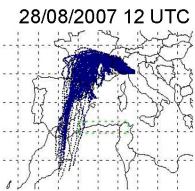
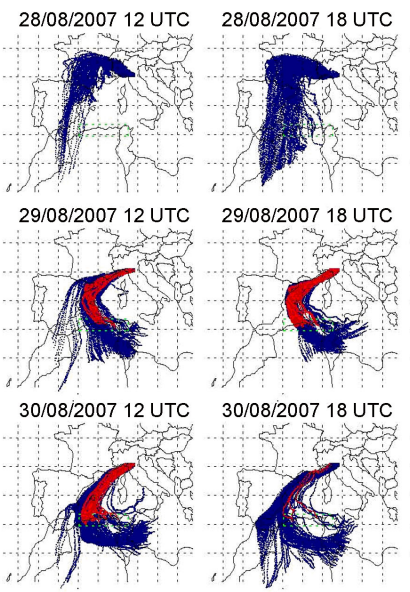

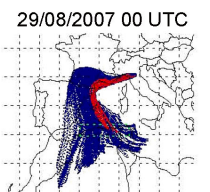

30/08/2007 00 UTC
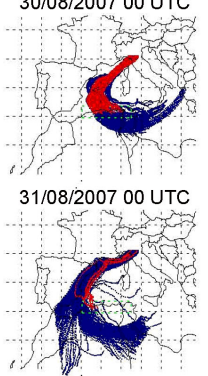
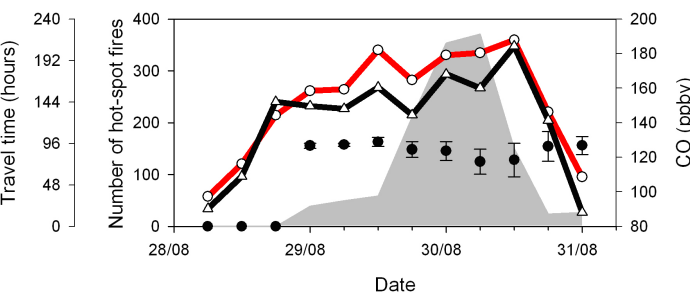
standard deviations (error bars).

Fig. 8. Back-trajectory ensemble for CMN from 28 August 2007 06:00 UTC to 31 August 2007 00:00 UTC. The back-trajectories which "intercepted" the active MODIS hot spot fires are highlighted in red.

that North African air masses reached CMN after travelling over potential source regions of mineral dust in the Sahara desert, as deduced by the analysis of OMI Aerosol Index gridded data (not shown). In the same period, several wildfires were also present along the North African coast line (see Sect. 3). To establish a possible source-receptor relationship between North African wildfires and trace gases and aerosol properties at CMN, we analysed BOLAM back-trajectories as a function of the geographic and temporal distribution of MODIS hot-spot fires. In particular, back-trajectories passing at less than $5 \mathrm{~km}$ (horizontal distance) from the locations of active MODIS hot-spot fires (red trajectories in Fig. 8), were selected as possibly influenced by BB products. In Fig. 9, the time series of the total number of intercepted MODIS hot-spot fires is reported together with the corresponding $3 \mathrm{~h}$ averages of $\mathrm{BC}$ and $\mathrm{CO}$ concentrations recorded at the measurement site. Starting from 29 August 2007 at 00:00 UTC, air masses which passed over MODIS hot-spot fires reached CMN (average transport times ranging from 75 to $93 \mathrm{~h}$ ), where the concentrations of BB tracers (i.e. $\mathrm{CO}$ and $\mathrm{BC}$ ) increased by about $50 \%$ in respect with values recorded on 28 August 2007 (Fig. 9). Note that the increase in CO and $\mathrm{BC}$ concentrations observed in the afternoon-evening on 28 August 2007, was not directly related with the BB product transport but with the advection of polluted air-masses from North Italy, as shown in the Sect. 3.2. Starting from $30 \mathrm{Au}-$ gust 2007 at 18:00 UTC, an evident decrease of CO and BC concentrations $(-35 \%)$ was recorded when atmospheric circulation and meteorological conditions changed, and wildfire locations were no longer intercepted by air masses reaching CMN.

The presence of mineral dust and BB products in air masses arriving at CMN from 29 to 30 August 2007 were confirmed by the chemical composition of aerosol parti-

Fig. 9. Comparison of the time series of $3 \mathrm{~h}$ measured $\mathrm{CO}$ and $\mathrm{BC}$ concentration at $\mathrm{CMN}$ (red and black lines, respectively) with the number of MODIS hot-spot fires (grey areas) intercepted by backtrajectories arriving at $\mathrm{CMN}$ at each $6 \mathrm{~h}$ time step. The average back-trajectory travel times (black dots) to reach CMN from the previous active MODIS hot-spot fire are reported together with their

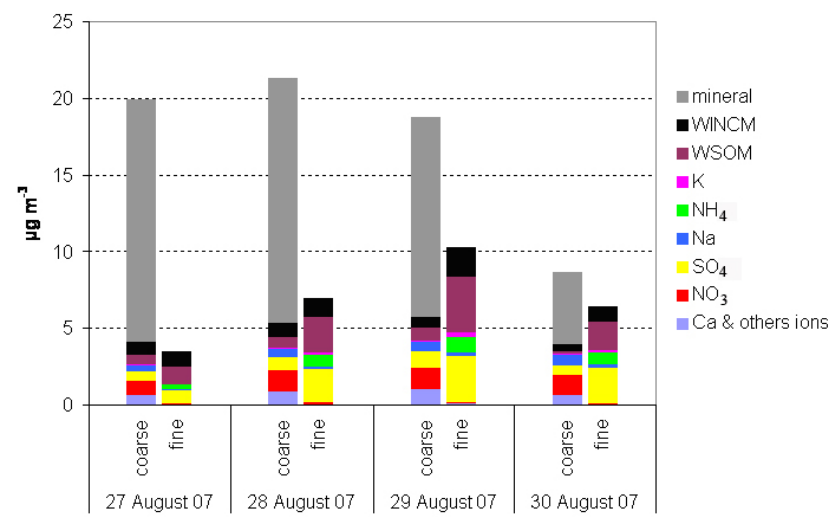

Fig. 10a. Chemical composition of coarse $\left(\mathrm{PM}_{1-10}\right)$ and fine $\left(\mathrm{PM}_{1}\right)$ fractions of aerosol at CMN from 27 to 30 August 2007. Dates in the $\mathrm{x}$-axis denote the starting day of each sampling. Note that on the fine fractions the analysis for mineral aerosol determination was not performed.

cles sampled during the event. As shown in Fig. 10a, in the first sampling period (27-28 August 2007), the $\mathrm{PM}_{1-10}$ chemical composition and mass concentration $\left(19.9 \mu \mathrm{g} / \mathrm{m}^{3}\right)$ clearly reflects the transport of Saharan dust rich in insoluble mineral oxides and $\mathrm{Ca}$ salts, whereas the mass concentrations of the aerosol components originating from combustion sources, i.e. $\mathrm{PM}_{1}$ particulate organic matter (WSOM+WINCM: $2.12 \mu \mathrm{g} / \mathrm{m}^{3} ; \mathrm{NO}_{3}^{-}: 0.06 \mu \mathrm{g} / \mathrm{m}^{3} ; \mathrm{SO}_{4}^{2}$ : $0.85 \mu \mathrm{g} / \mathrm{m}^{3}$ ), were in the lower range of summer average CMN levels (Marenco et al., 2006). The concentration of the chemical components in the coarse fraction $\left(\mathrm{PM}_{1-10}\right)$ remained high until 29-30 August $\left(18.7 \mu \mathrm{g} / \mathrm{m}^{3}\right)$, while those in the fine fraction $\left(\mathrm{PM}_{1}\right)$ underwent a significant increase, peaking on 29 August $2007\left(10.69 \mu \mathrm{g} / \mathrm{m}^{3}\right)$. Such trends are in close agreement with the time evolution of coarse and fine aerosol number concentrations (Fig. 1), respectively. On 29-30 August 2007, the $\mathrm{PM}_{1}$ particulate organic matter increased to $5.5 \mu \mathrm{g} / \mathrm{m}^{3}$, more than double the value on the first sampling day, as well as the summer background 


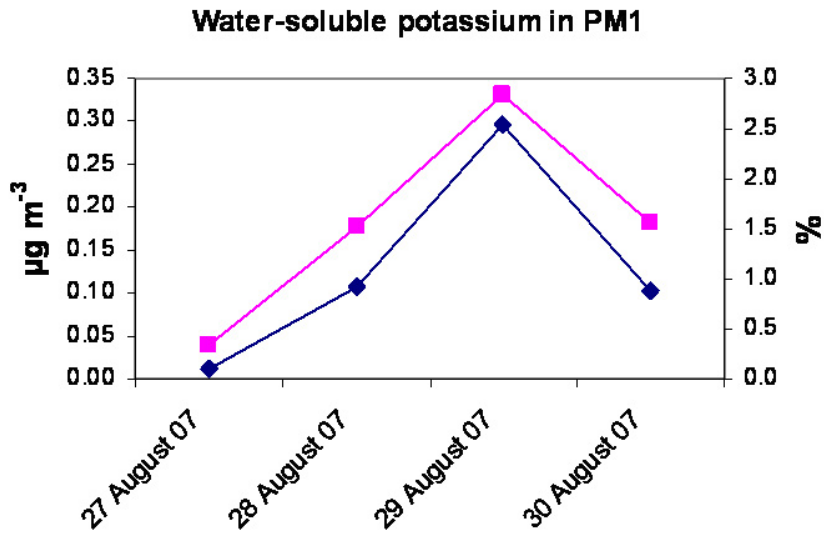

Fig. 10b. Concentration of water-soluble potassium in $\mathrm{PM}_{1}$ (blue line) and its contribution to the total $\mathrm{PM}_{1}$ mass reconstructed by the chemical analysis (purple line).

levels reported by Marenco et al. (2006). In the same period (Fig. 9), the equivalent BC concentration also experienced a large increase $(+124 \%)$, accounting for approximately half the water-insoluble carbonaceous matter (WINCM). However, the concentration increase of the more oxidised organic compounds was even more pronounced, so that the contribution of WSOM to total carbonaceous matter rose from 53\% to $65 \%$. This finding can be explained by the progressive substitution of organic material originating from fossil fuel combustion sources in the Po Valley on 27-28 August 2007 (see previous section), with BB aerosols enriched in WSOM (Decesari et al., 2006) on 29-30 August. The increase of the WSOM fraction could be partly due to aerosol ageing occurring during the transport of carbonaceous aerosols, which also supports the non-local source of the chemical components of $\mathrm{PM}_{1}$ during the event.

Mass concentrations of water-soluble ionic species in the $\mathrm{PM}_{1}$ fraction also exhibited an increasing trend starting from $27\left(1.5 \mu \mathrm{g} / \mathrm{m}^{3}\right)$ to 29 August $2007\left(5.0 \mu \mathrm{g} / \mathrm{m}^{3}\right)$, with $\mathrm{NO}_{3}^{-}, \mathrm{SO}_{4}^{2}, \mathrm{NH}_{4}^{+}$and $\mathrm{K}^{+}$as major contributing species (Fig. 10a). In particular, potassium in submicron particles, widely used as a tracer for BB plumes (Andreae, 1983; Ma et al., 2003), showed a significant increase in terms of both absolute concentrations and relative contribution to $\mathrm{PM}_{1}$ (Fig. 10b). As shown by Marenco et al. (2006), in summer 2004 at CMN the potassium average concentration was $0.036 \pm 0.025 \mu \mathrm{g} / \mathrm{m}^{3}$. On 27 August $2007 \mathrm{~K}^{+}$mass concentration was $0.012 \mu \mathrm{g} / \mathrm{m}^{3}$ whereas there was a large increase in potassium (up to ten times) in the subsequent three samples, reaching $0.297 \mu \mathrm{g} / \mathrm{m}^{3}$ on 29 August 2007. These results indicate that aerosol properties at CMN were strongly influenced by the North African BB products from 29 to 30 August 2007. Interestingly, the concentrations of another biomass smoke tracer, levoglucosan (Simoneit, 2002), fell under the detection limit $\left(20 \mathrm{ng} \mathrm{m}^{-3}\right)$ for all samples, meaning that levoglucosan accounted for less than $1 \%$ of the car- bonaceous organic matter during the expected peak of the $\mathrm{BB}$ event (on 29 August 2007), a finding in apparent contradiction with the potassium data. However, recent measurement of BB aerosol plumes in Africa (Capes et al., 2008) have revealed that levoglucosan accounted for a negligible fraction of organic matter in aged (4-8 days) wildfire plumes, and that the levoglucosan relative concentration to organic matter decreased progressively during transport. Therefore, the overall results of the chemical analyses strongly support the advection of aged BB aerosols mixed with mineral dust to CMN during 28-30 August 2007, with a peak of the BB contribution on 29 August 2007.

To evaluate the ERs of aerosol and $\mathrm{O}_{3}$, analysis was performed of the measurement period in which BOLAM showed at CMN the presence of air masses that had travelled over wildfires (i.e. 29 August 2007 23:00-30 August 2007 14:00). Excluded from the analysis were the data recorded on 29 August 2007 from 00:00 to 03:00 UTC+1, when high $\mathrm{O}_{3}$ values (up to $88 \mathrm{ppbv}$ ) were observed, without marked variations of $\mathrm{CO}$, suggesting possible mixing with other air masses.

The "scatterplot" analysis of aerosol properties and $\mathrm{O}_{3}$ as a function of $\mathrm{CO}$ concentrations revealed lower values of correlation coefficient than for the anthropogenic pollution plumes (Fig. 7). This is not surprising, considering the greater mixing and dilution that the air masses affected by BB might have experienced during the 3-4 days transport from the North African coastline. As shown in Table 2, during the $\mathrm{BB}$ period, the $\mathrm{BC} / \mathrm{CO}$ ERs were lower than those observed for the anthropogenic pollution. In literature, a broad range of $\mathrm{BC} / \mathrm{CO}$ ERs are reported for $\mathrm{BB}$ plumes due to the various processes acting both on the emission (i.e. fuel type, combustion efficiency) and transport (washout processes, air mass mixing, air mass age). Observations of boreal BB products (from North America and Siberia) at baseline stations in the Azores (PICO-NARE - $2200 \mathrm{~m}$ a.s.l.; Val Martin et al., 2006), Ireland (Mace Head; Forster at al., 2001) and Japan (Mt. Fuji - $3776 \mathrm{~m}$ a.s.l.; Kaneyasu et al., 2007) have shown ERs ranging from 0.5 to $8.4 \mathrm{ng} \mathrm{m}^{-3} / \mathrm{ppbv}$. Compared with such values, the higher ERs recorded at $\mathrm{CMN}$ for the North African BB plume suggest that the observed BC experienced very little removal during the 3-4 days of transport.

$V_{\text {fine }}$ and $\sigma_{p}$ also showed higher ERs than for the anthropogenic pollution plumes (Table 2), stressing the importance of the identified BB event as a source of atmospheric aerosol able to affect the atmospheric radiation budget. In this case, considering the number of fine particles instead of $V_{\text {fine }}$, ERs of $(0.87 \pm 0.04) \mathrm{cm}^{-3} / \mathrm{ppbv}$ and $(1.15 \pm 0.09) \mathrm{cm}^{-3} / \mathrm{ppbv}$ were obtained for "enhancement" and the "scatter" technique $\left(R^{2}=0.65\right)$, respectively. The $\sigma_{p} / \mathrm{CO}$ ER at CMN on 2930 August 2007 was in the range of values reported by other authors for long-range transport of BB smoke. Bertschi at al. (2004) and Bertschi and Jaffe (2005) calculated ER ranging from 0.24 to $1.24 \mathrm{Mm}^{-1} / \mathrm{ppbv}$ for very aged (7-10 days) Asian boreal fires. Airborne measurements carried out over 
the Amazon Basin in dry season 2006, have pointed out for typical BB emitted aerosol ERs of $0.36-0.40 \mathrm{Mm}^{-1} / \mathrm{ppbv}$ in the PBL and around $1.00 \mathrm{Mm}^{-1} / \mathrm{ppbv}$ in the free troposphere, indicating that the ageing process has an important effect on the optical and physical properties of BB-emitted aerosols (Chand et al., 2006).

The $\Delta \mathrm{O}_{3} / \Delta \mathrm{CO}$ values $(0.10-0.17 \mathrm{ppbv} / \mathrm{ppbv})$ were significantly lower (by a factor 3-4) than those observed for the anthropogenic pollution plume (Table 2). This could be explained by the lower $\mathrm{NO}_{\mathrm{x}}: \mathrm{CO}$ enhancement ratio in $\mathrm{BB}$ than in industrial or urban emissions (Wofsy et al., 1992; Andreae et al., 1994; McKeen et al., 2002; Pfister et al., 2006; Real et al., 2007). Moreover, due to the long-range transport, the observed BB plumes could have experienced more dilution and mixing than the air masses transported to CMN by the pollution event originating from northern Italy. The $\Delta \mathrm{O}_{3} / \Delta \mathrm{CO}$ values were obtained within the range of those reported by previous investigations for moderately aged (2-4 days) BB plumes (e.g. Wotawa and Trainer, 2000; McKeen et al., 2002; Yokelson et al., 2003; DeBell et al. 2004). Besides indicating the robustness of the identified plume origin, together with the enhanced $\mathrm{O}_{3}$ levels recorded at $\mathrm{CMN}$, such ERs indicate a probable significant $\mathrm{O}_{3}$ production occurred in the North African wildfire plume. However, it should be borne in mind that the presence of mineral dust could have partially hindered $\mathrm{O}_{3}$ production. A rough estimate of the mineral dust influence in limiting the observed $\mathrm{O}_{3}$ concentrations may be inferred from Bonasoni et al. (2004): for 12 Saharan dust events at CMN from June to December 2000, a $-8 \%$ (median value) $\mathrm{O}_{3}$ decrease with respect to monthly averages was observed. Assuming this value as representative for Saharan dust transport at $\mathrm{CMN}$, it can be supposed that without mineral dust a mean $\mathrm{O}_{3}$ concentration of $76 \mathrm{ppbv}(+19 \%$ with respect to summer 2007 mean value) and a $\mathrm{O}_{3} / \mathrm{CO}$ ERs of $0.16-0.19 \mathrm{ppbv} / \mathrm{ppbv}$ might characterise the detected BB plume.

\section{Discussion and conclusions}

By the end of August 2007, very high levels of trace gas (CO and $\mathrm{O}_{3}$ ), aerosol (equivalent $\mathrm{BC}, V_{\text {fine }}$ and $V_{\text {coarse }}$ ) and scattering coefficient were recorded at the regional GAW-WMO station of CMN (2165 m a.s.l., Italy). As deduced by air mass circulation analysis and aerosol chemical characterization, this was due to two different transport processes affecting the measurement site from 26 to 30 August 2007: transport of polluted air masses from northern Italy and transport of a BB product plume with mineral dust from North Africa. In particular, the high aerosol and ozone levels recorded at CMN during the transport of polluted air masses further emphasised the role of northern Italy as an efficient source region of anthropogenic pollution for the Mediterranean basin free troposphere. Even if $\mathrm{BB}$ transport to CMN were already observed during summer 2003 (Cristofanelli et al., 2006), this North African BB event constitutes the first investigation concerning an episode of wildfire product transport mixed with mineral dust at this measurement site, often considered representative for the background conditions of southern Europe/Mediterranean basin (Bonasoni et al., 2000; Fischer et al., 2003). To our knowledge, the present work is the first investigation on BB emissions from North African coastlines and is, therefore, an important contribution to improving the evaluation of sources of trace gases and aerosol over southern Europe/Mediterranean basin. In particular, while the export of mineral dust from the Sahara strongly affected the $V_{\text {coarse }}(+610 \%$ with respect to the summer 2007 average levels, $2.53 \mu \mathrm{m}^{3} \mathrm{~cm}^{-3}$ ), the products related to the $\mathrm{BB}$ event significantly increased the concentrations of $\mathrm{O}_{3}$ $(+11 \%), \mathrm{CO}(+63 \%), \mathrm{BC}(+271 \%), V_{\text {fine }}(+365 \%)$ and $\sigma_{p}$ coefficient $(+212 \%)$, as compared with the average summer 2007 levels (64 ppbv, $107 \mathrm{ppbv}, 273 \mathrm{ng} / \mathrm{m}^{3}, 0.82 \mu \mathrm{m}^{3} \mathrm{~cm}^{-3}$, $0.18 \mathrm{~cm}^{-3}, 27.0 \mathrm{Mm}^{-1}$, respectively). Moreover, the $\mathrm{CO}$ and aerosol levels recorded during the $\mathrm{BB}$ event were higher than during the anthropogenic pollution event $(\mathrm{CO}:+26 \%$, BC: $+39 \%, V_{\text {fine }}:+189 \%, \sigma_{p}:+100 \%$ ), indicating that in the considered period, North Africa represented a significant source of trace gas and aerosol particles over southern Europe and northern Italy. In fact, on 29-30 August 2007, high PM 10 values were recorded over the Po Basin by ARPA-ER: at a rural station located at the edge of Bologna urban area (Mt. Cuccolino, $60 \mathrm{~km}$ North-East to CMN), on 29 August $2007 \mathrm{PM}_{10}$ increased by $260 \%$ with respect to the August 2007 mean value $\left(9.6 \mu \mathrm{g} / \mathrm{m}^{3}\right)$. Even if no information is available on the $\mathrm{PM}_{10}$ chemical composition in the Po Basin, this suggests that the BB products mixed with Saharan dust from North Africa could have significantly influenced the lower troposphere over northern Italy.

As deduced from BOLAM three-dimensional backtrajectory analysis, during the BB event air masses travelled from 75 to $93 \mathrm{~h}$ from the wildfire area to CMN. Even if, due to the large emission variations between wildfires, caution should be deserved in directly relating BB plume ages and $\mathrm{O}_{3} / \mathrm{CO}$ ERs, this appears to be in good agreement with the $\mathrm{O}_{3} / \mathrm{CO}$ ER analysis. In fact, the calculated $\mathrm{O}_{3} / \mathrm{CO}$ ERs $(0.10-0.17 \mathrm{ppbv} / \mathrm{ppbv})$ was within the range of those reported by previous investigations for relatively aged (2-4 days) BB plumes. However, following Henne et al. (2008), it should be noted that since the regression slopes deduced by the "scatter technique" were obtained by applying a least squares regression, the obtained ERs can be underestimated. For this reason, we also calculated regression slopes by using the Reduced Major Axis (RMA) techniques, accounting for errors in both the $\mathrm{x}$ and the $\mathrm{y}$-variable. Nevertheless, due to the rather high $R^{2}$ observed only slight increases of regression slopes (and ERs) were calculated both for the pollution and the BB events. In particular, by considering the RMA technique, the $\mathrm{O}_{3} / \mathrm{CO}$ ER calculated by the "scatter" technique increase to $0.22 \mathrm{ppbv} / \mathrm{ppbv}$. 


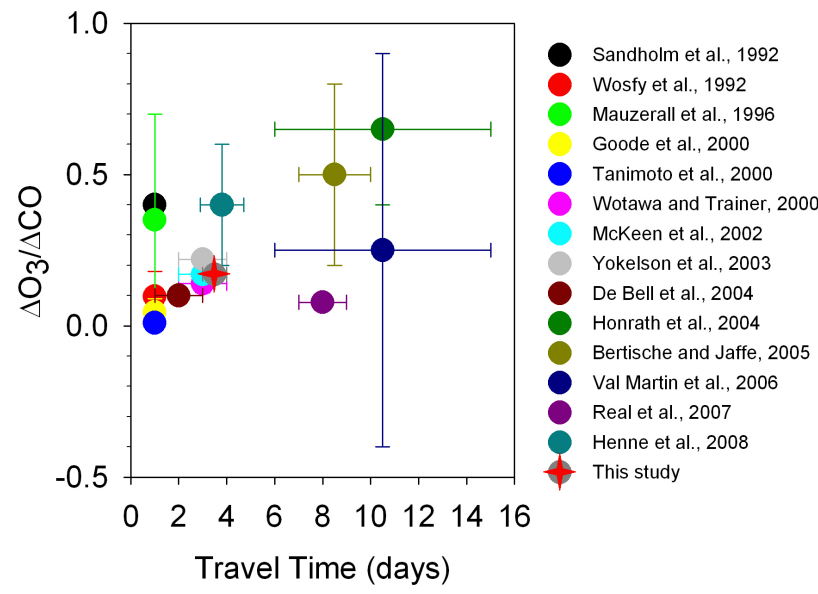

Fig. 11. ERs of $\mathrm{O}_{3}$ (relative to $\mathrm{CO}$ ) observed in previous investigations of $\mathrm{BB}$ plumes. Vertical bars denote the range of observed ERs. Horizontal bars denote the travel time for the observed BB plume.

The $\mathrm{O}_{3} / \mathrm{CO}$ ER values obtained at $\mathrm{CMN}$ and other locations during episodes of $\mathrm{BB}$ product transport are plotted as a function of air mass ageing (expressed as travel time) in Fig. 11, showing how ER increases with the ageing of air masses, suggesting $\mathrm{O}_{3}$ production within the $\mathrm{BB}$ plumes. Several investigators (e.g. Pfister et al., 2006; Val Martin et al., 2006; Real et al., 2007) have proposed that this could be the effect of the slow recycling of PAN, $\mathrm{HNO}_{3}$ and organic nitrates, which favour the photochemical formation of $\mathrm{O}_{3}$ in $\mathrm{BB}$ plumes by increasing the effective lifetime of $\mathrm{NO}_{2}$. Thus, even if lower than those during the pollution event, the obtained ERs and the high $\mathrm{O}_{3}$ levels support the hypothesis that significant photochemical $\mathrm{O}_{3}$ production occurred in the BB plume during transport towards CMN. However, it should be borne in mind that the mineral dust mixed within the $\mathrm{BB}$ plume could have partially hindered $\mathrm{O}_{3}$ production (Bonasoni et al., 2004). Even if the low $\mathrm{O}_{3}$ mixing ratios usually observed at CMN during Saharan dust events may be also related to the chemical properties of air-masses originating from North Atlantic and North Africa (Bonasoni et al., 2004), significant heterogeneous $\mathrm{O}_{3}$ destruction can occur on the surface of dust aerosols (Hanisch and Crowley, 2003; Bauer et al., 2004), while $\mathrm{HNO}_{3}$ and $\mathrm{NO}_{3}$ depletion on dust particles can remove a fraction of $\mathrm{O}_{3}$ precursors (Zhang and Carmichel, 1999; Harrison et al., 2001). In addition, mineral dust can cause a decrease in the photolysis rate throughout the troposphere, thus depressing the formation of $\mathrm{O}_{3}$ in the lower troposphere (Dentener et al., 1996; He and Carmichel, 1999; Balis et al., 2000). The possible influence of mineral dust in limiting $\mathrm{O}_{3}$ production within the $\mathrm{BB}$ plume was roughly inferred by considering the median $\mathrm{O}_{3}$ decrease (-8\%) observed by Bonasoni et al. (2004) during Saharan dust events at CMN. By applying this constant scaling factor to $\mathrm{O}_{3}$ during the $\mathrm{BB}$ event, an $\mathrm{O}_{3} / \mathrm{CO}$ ER of $0.16-0.19 \mathrm{ppbv} / \mathrm{ppbv}$ was obtained, still lower than that obtained for the anthropogenic pollution episode and still in agreement with BB products 2-4 days old (Fig. 11).

During the drought periods that frequently affect the Mediterranean basin (particularly during the summer months), BB products can be often found to affect the Mediterranean basin (Sciare et al., 2003; Pace et al., 2005, 2006; Cristofanelli et al., 2006). In particular, by analysing the behaviour of fine light-absorbing aerosol in the central Mediterranean during summer 2003, Pace et al. (2005) estimated that the particles emitted by the forest fires over South Europe produced an increase of heating rate as large as $2.8 \mathrm{~K} /$ day at the altitude of the aerosol layer, thus probably affecting also the atmospheric circulation by increasing the atmospheric stability. Moreover, it is well known that also mineral dust plays important role on the climatic system (e.g. Forster et al., 2007) and the importance of Saharan dust as source of mineral aerosol for the Mediterranean basin is indicated by several investigations. In fact, during a 11-year period (1983-1994) Moulin et al. (1997) reported 16 Saharan dust events per year over western Mediterranean, while recent results from EARLINET (European Aerosol Research Lidar Network) activity showed that, depending on the geographical location, over the Mediterranean basin from 12 to 35 days per year can be affected by Saharan dust outbreaks (Papayannis et al., 2008). Similar results were presented by Marinoni et al. (2008) who identified an average of 40 days per year as influenced by Saharan dust events at CMN and by Collaud Coen et al. (2004) who found 48 dust events from March 2001-December 2002 at the Jungfraujoch alpine station. Because it is expected that North Africa and Mediterranean basin will probably experience more frequent and severe droughts in the near future (Christensen et al., 2007; Solomon et al., 2007), such events might gain further importance, as sources of atmospheric compounds able to exert an influence on the regional climate and on the tropospheric composition over South Europe/Mediterranean basin.

Thus, since tropospheric $\mathrm{O}_{3}$ and aerosol particles strongly influence the radiative budget of the atmosphere (Forster et al., 2007), the present results suggest that episodes of wildfire product and mineral dust emissions from North Africa can play a significant role in influencing radiative properties (as also suggested by the $\mathrm{BC}$ and $\sigma_{p}$ measurements at $\mathrm{CMN}$ ) and air quality over the Mediterranean basin. However, to better clarify the potential role of these classes of events (mineral dust transport, BB product transport as well as concurring BB product and mineral dust transport) in influencing systematically the composition of the troposphere over the Mediterranean region, a multi-year climatological investigation appears as an important step.

Acknowledgements. This work was supported by the EV-K ${ }^{2}$-CNR SHARE project and the EU Network of Excellence ACCENT. Part of the aerosol measurements carried out at CMN were conducted in the framework of the EU-projects EUSAAR and EUCAARI, and of the national project AEROCLOUDS. F. Fierli and P. Messina were partially supported by the ASI (Italian Space Agency) QUITSAT 
project. The authors thank the Italian Air Force (CAMM Mt. Cimone and Meteorological Service) for the fruitful collaboration at Mt. Cimone. The authors are also grateful to NASA/GSFC and the University of Maryland for providing MODIS Hotspot Active Fire data, to the NASA Goddard Earth Sciences (GES) Data and Information Services Center (DISC), NASA/GSFC and KNMI for providing OMI Aerosol Index data from the the Giovanni online data system, to ARPA-ER (Dr. Stefano Zauli-Sajani) for providing surface $\mathrm{O}_{3}$ data in Modena and $\mathrm{PM}_{10}$ data at Mt. Cuccolino. FLEXTRA back-trajectories, calculated using meteorological data provided by the ECMWF (European Centre for Medium Range Weather Forcast), were obtained by Andreas Stohl (NILU) in cooperation with Gerhard Wotawa and Petra Seibert (Institute of Meteorology and Geophysics, Vienna).

Edited by: A. S. H. Prevot

\section{References}

Andreae, M. O.: Soot carbon and excess fine potassium: Longrange transport of combustion-derived aerosols, Science, 220, 1148-1151, 1983.

Andreae, M. O., Anderson, B. E., Blake, D. R., Bradshaw, J. D., Collins, J. E., Gregory, G. L., Sachse, G. W., and Shipham, M. C.: Influence of plumes from biomass burning on atmospheric chemistry over the equatorial and tropical South Atlantic during CITE 3, J. Geophys. Res., 99, 12793-12808, 1994.

Andreae, M. O. and Merlet, P.: Emission of trace gases and aerosols from biomass burning, Global Biogeochem. Cy., 15, 955-966, 2001.

Andreae, M. O. and Gelencsr, A.: Black carbon or brown carbon? The nature of light-absorbing carbonaceous aerosols, Atmos. Chem. Phys., 6, 3131-3148, 2006,

http://www.atmos-chem-phys.net/6/3131/2006/.

Balis, D. S., Zerefos, C. S., Kourtidis, K., Bais, F., Hofzumahaus, A., Kraus, R., Schmitt, M., and Gobbi, G. P.: Measurements and modeling of photolysis rates during the Photochemical Activity and Ultraviolet Radiation (PAUR) II campaign, J. Geophys. Res., 107(D18), 8138, doi:10.1029/2000DJ000136, 2002.

Baltensperger, U., Gaeggeler, H. W., Jost, D. T., Lugauer, M., Schwikowski, M., Weingartner, E., and Seibert, P.: Aerosol climatology at the high-alpine site Jungfraujoch, Switzerland, J. Geophys. Res., 102(D16), 19707-19715, 1997.

Bauer, S. E., Balkanski, Y., Schulz, M., Hauglustaine, D. A., and Dentener, F.: Global modeling of heterogeneous chemistry on mineral aerosol surfaces: Influence on tropospheric ozone chemistry and comparison to observations, J. Geophys. Res., 109, D02304, doi:10.1029/2003JD003868, 2004.

Beck, J. P., Asimakopoulos, N., Bazanov, V., Bock, H. J., Chronopoulos, G., De Muer, D., Ebel, A., Flatoey, F., Hass, H., Van Haver, P., Hov, O., Jakobs, H. J., Kirchner, E. J., Kunz, H.; Memmersheimer, M., Van Pul, W. A. J., Speth, P., Trickl, T., and Varotsos, C.: Exchange of ozone between the atmospheric boundary layer and the free troposphere. In: Tropospheric ozone research - Tropospheric ozone in the regional and sub-regional context (Transport and chemical transformation of pollutants in the troposphere 6), edited by: Hov, O., Kley, D., EUROTRAC International Scientific Secretariat, GarmischPartenkirchen, Berlin: Springer, 1997.
Bertschi, I. T., Jaffe, D. A., Jaegl, L., Price, H. U., and Dennison, J. B.: PHOBEA/ITCT 2002 airborne observations of transpacific transport of ozone, $\mathrm{CO}$, volatile organic compounds, and aerosols to the northeast Pacific: Impacts of Asian anthropogenic and Siberian boreal fire emissions, J. Geophys. Res., 109, D23S12, doi:10.1029/2003JD004328, 2004.

Bertschi, I. T. and Jaffe, D. A.: Long-range transport of ozone, carbon monoxide, and aerosols to the NE Pacific troposphere during the summer of 2003: Observations of smoke plumes from Asian boreal fires, J. Geophys. Res., 110(D5), D05303, doi:10.10292004JD005135, 2005.

Bonasoni, P., Stohl, A., Cristofanelli, P., Calzolari, F., Colombo, T., and Evangelisti, F.: Background ozone variations at Mt. Cimone Station, Atmos. Environ., 34, 5183-5189, 2000.

Bonasoni, P., Cristofanelli, P., Calzolari, F., Bonaf, U., Evangelisti, F., Stohl, A., Zauli Sajani, S., van Dingenen, R., Colombo, T., and Balkanski, Y.: Aerosol-ozone correlations during dust transport episodes, Atmos. Chem. Phys., 4, 1201-1215, 2004, http://www.atmos-chem-phys.net/4/1201/2004/.

Bond, T. C., Streets, D. G., Yarber, K. F., et al.: A technologybased global inventory of black carbon and organic carbon emissions from combustion, J. Geophys. Res., 109, D14203, doi:10.1029/2003JD003697, 2004.

Brunekreef, B. and Holgate, S.: Air pollution and health, Lancet, 360, 1233-1242, 2002.

Buzzi, A. and Foschini, L.: Mesoscale meteorological features associated with heavy precipitation in the southern Alpine region, Meteorol. Atmos. Phys., 72, 131-146, 2000.

Calzolai, G., Chiari, M., García Orellana, I., Lucarelli, F., Migliori, A., Nava, S., and Taccetti, F.: The new external beam facility for environmental studies at the Tandetron accelerator of LABEC, Nucl. Instr. and Meth., B249, 928-931, 2006

Capes, G., Johnson, B., McFiggans, G., Williams, P. I., Haywood, J., and Coe, H.: Aging of biomass burning aerosols over West Africa: Aircraft measurements of chemical composition, microphysical properties, and emission ratios, J. Geophys. Res., 113, D00C15, doi:10.1029/2008JD009845, 2008.

Carnuth, W., Kempfer, U., and Trickl, T.: Highlights of the Tropospheric Lidar Studies at IFU within the TOR Project, Tellus B, 54, 163-185, 2002.

Chand, D., Guyon, P., Artaxo, P., Schmid, O., Frank, G. P., Rizzo, L. V., Mayol-Bracero, O. L., Gatti, L. V., and Andreae, M. O.: Optical and physical properties of aerosols in the boundary layer and free troposphere over the Amazon Basin during the biomass burning season, Atmos. Chem. Phys., 6, 2911-2925, 2006

Chen, L.-W. A., Doddridge, B. G., Dickerson, R. R., Chow, J. C., Mueller, P. K., Quinn, J., and Butler, W. A.: Seasonal variations in elemental carbon aerosol, carbon monoxide and sulfur dioxide: Implications for sources, Geophys. Res. Lett., 28, 171111714, 2001.

Chin, M., Jacob, D. J., Munger, J. W., Parrish, D. D., and Doddridge, B. G.: Relationship of ozone and carbon monoxide over North America, J. Geophys. Res., 99, 14565-14573, 1994.

Christopher, S. A., Li, X., Welch, R. M., Reid, J. S., Hobbs, P. V., Eck, T. F., and Holben, B.: Estimation of surface and top-ofatmosphere (TOA) shortwave irradiance in biomass-burning regions during SCAR-B, J. Appl. Meteorol., 39, 1742-1753, 2000.

Christensen, J. H., Hewitson, B., Busuioc, A., Chen, A., Gao, X., Held, I., Jones, R., Kolli, R. K., Kwon, W.-T., Laprise, R., 
Magaña Rueda, V., Mearns, L., Menéndez, C. G., Räisänen, J., Rinke, A., Sarr, A., and Whetton, P.: Regional Climate Projections, in: Climate Change 2007: The Physical Science Basis. Contribution of Working Group I to the Fourth Assessment Report of the Intergovernmental Panel on Climate Change, Cambridge University Press, Cambridge, United Kingdom and New York, NY, USA, 848-940, 2007.

Cristofanelli, P., Bonasoni, P., Carboni, G., Calzolari, F., Casarola, L., Zauli Sajani, S., and Santaguida, R.: Anomalous high ozone concentrations recorded at a high mountain station in Italy in summer 2003, Atmos. Environ., 41, 1383-1394, 2007.

Crutzen, P. J. and Andreae, M. O.: Biomass burning in the tropics: Impact on atmospheric chemistry and biogeochemical cycles, Science, 250, 1669-1678, 1990.

Crutzen, P. J., Lawrence, M. G., and Pöschl, U.: On the background photochemistry of tropospheric ozone, Tellus, 51, 123146, 1999.

DeBell, L. J., Talbot, R. W., Dibb, J. E., Munger, J.W., Fischer, E. V., and Frolking, S. E.: A major regional air pollution event in the northeastern United States caused by extensive forest fires in Quebec, Canada, J. Geophys. Res., 109, D19305, doi:10.1029/2004JD004840, 2004.

Decesari, S., Fuzzi, S., Facchini, M.C., Mircea, M., Emblico, L., Cavalli, F., Maenhaut, W., Chi, X., Schkolnik, G., Falkovich, A., Rudich, Y., Claeys, M., Pashynska, V., Vas, G., Kourtchev, I., Vermeylen, R., Hoffer, A., Andreae, M.O., Tagliavini, E., Moretti, F., and Artaxo, P.: Characterization of the organic composition of aerosols from Rondônia, Brazil, during the LBASMOCC 2002 experiment and its representation through model compounds, Atmos. Chem. Phys., 6, 375-402, 2006,

http://www.atmos-chem-phys.net/6/375/2006/.

Dentener, F. J. and Crutzen, P. J.: Reaction of $\mathrm{N}_{2} \mathrm{O}_{5}$ on tropospheric aerosol: Impact on the global distributions of $\mathrm{NO}_{\mathrm{x}}, \mathrm{O}_{3}$, and $\mathrm{OH}$, J. Geophys. Res., 98, 7149-7162, 1993.

Dentener, F. J., Carmichael, G. R., Zhang, Y., Lelieveld, J., and Crutzen, P. J.: The role of mineral aerosols as a reactive surface in the global troposphere, J. Geophys. Res., 101, 22 869-22 889, 1996.

Duncan, B. N., West, J. J., Yoshida1, Y., Fiore, A. M., and Ziemke, J. R.: The influence of European pollution on ozone in the Near East and northern Africa, Atmos. Chem. Phys., 8, 2267-2283, 2008 , http://www.atmos-chem-phys.net/8/2267/2008/.

Fierli, F., Di Donfrancesco, G., Cairo, F., Marécal, V., Zampieri, M., Orlandi, E., and Durry, G.: Variability of cirrus clouds in a convective outflow during the Hibiscus campaign, Atmos. Chem. Phys. 8, 4547-4558, 2008.

Fischer, H., Brunner, D., Harris, G. W., Hoor, P., Lelieveld, J., McKenna, D. S., Rudolph, J., Scheeren, H. A., Siegmund, P., Wernli, H., Williams, J., and Wong, S.: Synoptic tracer gradients in the upper troposphere over central Canada during the STREAM 1998 summer campaign, J. Geophys. Res., 107(8), 4064, doi:10.1029/2000JD000312, 2002.

Fischer, H., Kormann, R., Klüpfel, T., Gurk, C., Königstedt, R., Parchatka, U., Mühle, J., Rhee, T. S., Brenninkmeijer, C. A. M., Bonasoni, P., and Stohl, A.: Ozone production and trace gas correlations during the June 2000 MINATROC intensive measurement campaign at Mt. Cimone, Atmos. Chem. Phys., 3, 725-738, 2003 , http://www.atmos-chem-phys.net/3/725/2003/.

Fishman, J., Seiler, W., and Haagenson, P.: Simultaneous presence of $\mathrm{O}_{3}$ and $\mathrm{CO}$ bands in the troposphere, Tellus, 32, 456-463, 1980.

Forster, C., Wandinger, U., Wotawa, G., et al.: Transport of boreal forest fire emissions from Canada to Europe, J. Geophys. Res., 106, 22,887-22,906, 2001.

Forster, P., Ramaswamy, V., Artaxo, P., Berntsen, T., Betts, R., Fahey, D. W., Haywood, J., Lean, J., Lowe, D. C., Myhre, G., Nganga, J., Prinn, R., Raga, G., Schulz M., and Van Dorland, R.: Changes in Atmospheric Constituents and in Radiative Forcing, in Climate Change 2007: The Physical Science Basis. Contribution of Working Group I to the Fourth Assessment Report of the Intergovernmental Panel on Climate Change, edited by: Solomon, S., Qin, D., Manning, M., Chen, Z., Marquis, M., Averyt, K. B., Tignor M., Miller, H. L., Cambridge University Press, Cambridge, United Kingdom and New York, NY, USA, 2007.

Gauss, M., Myhre, G., Pitari, G., et al.: Radiative forcing in the 21 st century due to ozone changes in the troposphere and the lower stratosphere, J. Geophys. Res., 108, 4292, doi:10.1029/2002JD002624, 2003.

Gheusi, F. and Stein, J.: Lagrangian description of airflows using Eulerian passive tracers, Q. J. Roy. Meteorol. Soc., 128, 337360, 2002.

Giglio, L., Descloitres, J., Justice, C. O., et al.: An Enhanced Contextual Fire Detection Algorithm for MODIS, Rem. Sens. Environ., 87(2-3), 273-282, 2003.

GAW: report of the WMO meeting of experts on the quality assurance plan for the Global Atmospheric Watch (GAW), GarmischPartenkirchen, Germany, 26-30 March, 1992.

Goode, J., Yokelson, R. J., Ward, D. E., Babbit, R. E., Davies, M. A., and Hao, W. M.: Measurements of excess $\mathrm{O}_{3}, \mathrm{CO}_{2}$, $\mathrm{CH}_{4}, \mathrm{C}_{2} \mathrm{H}_{2}, \mathrm{HCN}, \mathrm{NO}, \mathrm{NH}_{3}, \mathrm{HCOOH}, \mathrm{CH}_{3} \mathrm{COOH}, \mathrm{HCHO}$ and $\mathrm{CH}_{3} \mathrm{OH}$ in 1997 Alaskan biomass burning plumes by airborne Fourier transform spectroscopy (AFTIR), J. Geophys. Res., 105, 22147-22166, 2000.

Harrison, S. P., Kohfeld, K. E., Roelandt, C., and Claquin, T.: The role of dust in climate changes today, at the Last Glacial Maximum and in the future. Earth-Sci. Rev., 54, 43-80, 2001.

Hanisch, K. and Crowley, J. N.: Ozone decomposition on Saharan dust: an experimental investigation, Atmos. Chem. Phys., 3, 119-130, 2003,

http://www.atmos-chem-phys.net/3/119/2003/.

He, S. and Carmichel, G. R.: Sensitivity of photolysis rates and ozone production in the troposphere to aerosol properties, J. Geophys. Res., 104, D21, 26307-26324, 1999.

Henne, S., Furger, M., Nyeki, S., Steinbacher, M., Neininger, B., de Wekker S. F. J., Dommen, J., Spichtinger, N., Stohl, A., and Prévôt, A. S. H.: Quantification of topographic venting of boundary layer air to the free troposphere, Atmos. Chem. Phys., 4, 497509, 2004,

http://www.atmos-chem-phys.net/4/497/2004/.

Henne, S., Dommen, J., Neininger, B., Reimann, S., Staehelin, J., and Prévôt, A. S. H.: Influence of mountain venting in the Alps on the ozone chemistry of the lower free troposphere and the European pollution export, J. Geophys. Res., 110, D22307, doi:10.1029/2005JD005936, 2005a.

Henne, S., Furger, M., and Prévôt, A. S. H.: Climatology of mountain venting induced moisture layers in the lee of Alps, J. Appl. 
Meteo., 44, 620-633, 2005b.

Henne, S., Klausen, J., Junkermann, W., Kariuki, J. M., Aseyo, J. O., and Buchmann, B.: Representativeness and climatology of carbon monoxide and ozone at the global GAW station Mt. Kenya in equatorial Africa, Atmos. Chem. Phys., 8, 31193139, 2008,

http://www.atmos-chem-phys.net/8/3119/2008/.

Hodzic, A., Madronich, S., Bohn, B., Massie, S., Menut, L., and Wiedinmyer, C.: Wildfire particulate matter in Europe during summer 2003: meso-scale modeling of smoke emissions, transport and radiative effects, Atmos. Chem. Phys., 7, 4043-4064, 2007

Hogan, T.E., and Rosmond, T.E.: The description of the Navy operation global atmospheric prediction system's spectral forecast model, Mon. Wea. Rev., 119, 1786-1815, 1991.

Hogan, T. F. and Brody, L. R.: Sensitivity studies of the Navy's global forecast model parameterizations and evaluation of improvement to NOGAPS, Mon. Weather Rev., 121, 2373-2395, 1993.

Honrath, R. E., Owen, R. C., Val Martìn, M., Reid, J. S., Lapina, K., Fialho, P., Dziobak, M. P., Kleissl, J., and Westphal, D. L.: Regional and hemispheric impacts of anthropogenic and biomass burning emissions on summertime $\mathrm{CO}$ and $\mathrm{O}_{3}$ in the North Atlantic lower free troposphere, J. Geophys. Res., 109, D24310, doi:10.1029/2004JD005147, 2004.

Hsu, N. C. Herman, J. R., Gleason, J. F., et al.: Satellite detection of smoke aerosols over a snow/ice surface by TOMS, Geophys. Res. Lett., 23, 1165-1168, 1999.

Li, C., Marufu, L. T., Dickerson, R. R., Li, Z., Wen, T., Wang, Y., Wang, P., Chen, H., and Stehr, J. W.: In situ measurements of trace gases and aerosol optical properties at a rural site in northern China during East Asian Study of Tropospheric Aerosols: An International Regional Experiment 2005, J. Geophys. Res., 112(D22), D22S04, doi:10.1029/2006JD007592, 2006.

Jaffe, D., Anderson, T., Covert, D., Trost, B., Danielson, J., Simpson, W., Blake, D., Harris, J., and Streets, D.: Observations of ozone and related species in the northeast Pacific during the PHOBEA campaigns 1. Ground-based observations at Cheeka Peak, J. Geophys. Res., 106(D7), 7449-7461, 2001.

Jennings, S., Spain, T., Doddridge, B., Maring, H., Kelly, B., and Hansen, A.: Concurrent measurements of black carbon aerosol and carbon monoxide at Mace Head, J. Geophys. Res., 101(D14), 19447-19454, 1996.

Justice, C. O., Giglio, L., Korontzi, S., Owens, J., Morisette, J. T., Roy, D., Descloitres, J., Alleaume, S., Petitcolin, F., and Kaufman, Y.: The MODIS fire products, Rem. Sens. Environ., 83, 244-262, 2002.

Kaiser, J. W., Morcrette, J.-J., Serrar, S., Engelen, R., Sofiev, M., Schultz, M. G., van der Werf, G., Wooster, M., Roberts, G., Heil, A., Boucher, O., Kinne, S., Doutriaux-Boucher, M., Jones, L., Govaerts, Y., and Lattanzio, A.: Modelling the Impact of Biomass Burning on Atmospheric Aerosol and Greenhouse Gas Abundances, Geophys. Res. Abstr., Vol.10, EGU2008-A-04839, 2008.

Kaneyasu N., Igarashi, Y., Sawa, Y., Takahashi, H., Takada, H., Kumata, H., and Höller, R.: Chemical and optical properties of 2003 Siberian forest fire smoke observed at the summit of Mt. Fuji, Japan, J. Geophys. Res., 112, D13214, doi:10.1029/2007JD008544, 2007.
Kasischke, E. S., Hyer, E., Novelli, P., Bruhwiler, L., French, N., Sukhinin, A., Hewson, J., and Stocks, B.: Influences of boreal fire emissions on Northern Hemisphere atmospheric carbon and carbon monoxide, Global Biogeochem. Cy., 19, GB1012, doi:10.1029/2004GB002300, 2005.

Le Page, Y., Pereira, J. M. C., Trigo, R., da Camara, C., Oom, D., and Mota, B.: Global fire activity patterns (1996-2006) and climatic influence: an analysis using the World Fire Atlas, Atmos. Chem. Phys., 8, 1911-1924, 2008,

http://www.atmos-chem-phys.net/8/1911/2008/.

Lelieveld, J., Berresheim, H., Borrmann, S., Crutzen, P. J., Dentener, F. J., Fischer, H., Feichter, J., Flatau, P. J., Heland, J., Holzinger, R., Kormann, R., Lawrence, M. B., Levin, Z., Markowicz, K., Mihalopoulos, N., Minikin, A., Ramanthan, V., de Reus, M., Roelofs, G. J., Scheeren, H. A., Sciare, J., Schlager, H., Schulz, M., Siegmund, P., Steil, B., Stephanou, E. G., Stier, P., Traub, M., Warneke, C., Williams, J., and Ziereis, H.: Global air pollution crossroads over the Mediterranean, Science 298, 794-799, 2002.

Lohmann, U, Feichter, J., Penner, J. E., and Leaitch, W. R.: Indirect effect of sulfate and carbonaceous aerosols: A mechanistic treatment, J. Geophys. Res., 105, 12193-12206, 2000.

Ma, Y., Weber, R. J., Lee, Y.-N., et al.: Characteristics and influence of biosmoke on the fine-particle ionic composition measured in Asian outflow during the Transport and Chemical Evolution Over the Pacific (TRACE-P) experiment, J. Geophys. Res., 108(D21), 8816, doi:10.1029/2002JD003128, 2003.

Marenco, F., Bonasoni, P., Calzolari, F., et al.: Characterization of atmospheric aerosol at Monte Cimone, Italy, during summer 2004: source apportionment and transport mechanisms, J. Geophys. Res., 111, D24202, doi:10.1029/2006JD007145, 2006.

Marinoni, A., Cristofanelli, P., Calzolari, F., Roccato, F., Bonafè, U., and Bonasoni, P.: Continuous measurements of aerosol physical parameters at the Mt. Cimone GAW Station (2165 m a.s.l., Italy), Sci. Tot. Environ., 391, 241-251, 2008.

McKeen, S. A., Wotawa, G., Parrish, D. D., Holloway, J. S., Buhr, M. P., Hübler, G., Fehsenfeld, F. C., and Meagher, J. F.: Ozone production from Canadian wildfires during June and July of 1995, J. Geophys. Res., 107(D14), 4192, doi:10.1029/2001JD000697, 2002.

Matta, E., Facchini, M. C., Decesari, S., Mircea, M., Cavalli, F., Fuzzi, S., Putaud, J.-P., and Dell'Acqua, A.: Mass closure on the chemical species in size-segregated atmospheric aerosol collected in an urban area of the Po Valley, Italy, Atmos. Chem. Phys., 3, 623-637, 2003, http://www.atmos-chem-phys.net/3/623/2003/.

Mauzerall, D., Jacob, D., Fan, S.-M., Bradshaw, J., Gregory, G., Sachse, G., and Blake, D.: Origin of tropospheric ozone at remote high northern latitudes in summer, J. Geophys. Res., 101(D2), 4175-4188, 1996.

Millàn, M., Sanz, J., Salvador, R., and Mantilla, E.: Atmospheric dynamics and ozone cycles related to nitrogen deposition in the western Mediterranean, Environ. Poll., 118, 167-186, 2006.

Muoillot, F. and Field, C. B.: Fire history and the global carbon budget: a $1^{\circ} \times 1^{\circ}$ fire history reconstruction for the 20th century, Glob. Chang. Biol., 11, 398-420, 2005.

Novelli, P. C., Steele, L. P., and Tans, P. P.: Mixing ratios of carbon monoxide in the troposphere, J. Geophys. Res., 97(D18), 2073120750, 1992. 
Novelli, P. C.: CO in the atmosphere: measurement techniques and related issues, Chemosphere, Global Change Sci., 1, 115-126, 1999.

Novelli, P. C., Masarie, K. A., Lang, P. M., Hall, B. D., Myers, R. C., and Elkins, J. W.: Reanalysis of tropospheric CO trends: Effects of the 1997-1998 wildfires, J. Geophys. Res., 108(D15), 4464, doi:10.1029/2002JD003031, 2003.

Pace, G., Meloni, D., and di Sarra, A.: Forest fire aerosol over the Mediterranean basin during summer 2003, J. Geophys. Res., 110, D21202, doi:10.1029/2005JD005986, 2005.

Pace, G., di Sarra, A., Meloni, D., Piacentino, S., and Chamard, P.: Aerosol optical properties at Lampedusa (Central Mediterranean). 1. Influence of transport and identification of different aerosol types, Atmos. Chem. Phys., 6, 697-713, 2006, http://www.atmos-chem-phys.net/6/697/2006/.

Papayannis, A., Amiridis, V., Mona, L., et al.: Systematic lidar observations of Saharan dust over Europe in the frame of EARLINET (2000-2002), J. Geophys. Res., 113, D10204, doi:10.1029/2007JD009028, 2008.

Parrish, D. D., Holloway, J. S., Trainer, M., Murphy, P. C., Forbes, G. L., and Fehsenfeld, F. C.: Export of North American ozone pollution to the North Atlantic Ocean, Science, 259, 1436-1439, 1993.

Parrish, D. D., Trainer, M., Holloway, J. S., Yee, J. E., Warshawsky, M., Fehsenfeld, F. C., Forbes, G. L., and Moody, J. L.: Relationships between ozone and carbon monoxide at surface sites in the North Atlantic region, J. Geophys. Res., 103, 13357-13376, 1998.

Pfister G. G., Emmons, L. K., Hess, P. G., et al.: Ozone production from the 2004 North American boreal fires, J. Geophys. Res., 111, D24S07, doi:10.1029/2006JD007695, 2006.

Petzold, A., Kramer, H., and Schönlinner, M.: Continuous measurement of atmospheric black carbon using a multi-angle absorption photometer, Environ. Sci. Pollut. Res., 4, 78-82, 2002

Price, H. U., Jaffe, D. A., Cooper, O. R., and Doskey, P. V.: Photochemistry, zone production, and dilution during long-range transport episodes from Eurasia to the northwest United States, J. Geophys. Res., 9, D23S13, doi:10.1029/2003JD004400, 2004.

Putaud, J.-P., Van Dingenen, R., Dell'Acqua, A., Raes, F., Matta, E., Decesari S., Facchini, M.C., and Fuzzi, S.: Size-segregated aerosol mass closure and, chemical composition in Monte Cimone (I) during MINATROC, Atmos. Chem. Phys., 4, 889-902, 2004,

http://www.atmos-chem-phys.net/4/889/2004/.

Real, E., Law, K. S., Weinzierl, B., et al.: Processes influencing ozone levels in Alaskan forest fire plumes during longrange transport over the North Atlantic, J. Geophys. Res., 112, D10S41, doi:10.1029/2006JD007576, 2007.

Rinaldi, M., Emblico, L., Decesari, S., Fuzzi, S., Facchini, M. C., and Librando, V.: Chemical characterization and source apportionment of size-segregated aerosol collected at an urban site in Sicily, Water Air Soil Pollut., 185, 311-321, 2007.

Sandholm, S. T., Bradshaw, J. D., Chen, G., et al.: Summertime tropospheric observations related to $\mathrm{N}_{\mathrm{x}} \mathrm{O}_{\mathrm{y}}$ distributions and partitioning over Alaska: Arctic Boundary Layer Expedition 3A, J. Geophys. Res., 97(D15), 16481-16509, 1992.

Sciare, J., Bardouki, H., Moulin, C., and Mihalopoulos, N.: Aerosol sources and their contribution to the chemical composition of aerosols in the Eastern Mediterranean Sea during summertime,
Atmos. Chem. Phys., 3, 291-302, 2003,

http://www.atmos-chem-phys.net/3/291/2003/.

Scheel, H. E., Areskoug, H., Geiß, H., Gomiscek, B., Granby, K., Haszpra, L., Klasinc, L., Kley, D., Laurila, T., Lindskog, A., Roemer, M., Schmitt, R., Simmonds, P., Solberg, S., and Toupance, G.: On the spatial distribution and seasonal variation of lower-troposphere ozone over Europe, J. Atmos. Chem., 28, 11-28, 1997.

Schkolnik, G. and Rudich, Y.: Detection and quantification of levoglucosan in atmospheric aerosols: a review, Anal. Bioanal. Chem. 385, 26-33, 2006.

Schuepbach, E., Zanis, T. F. P., Monks, P., and Penkett, S.: State space analysis of changing seasonal ozone cycles (1988-1997) at Jungfraujoch (3580 m a.s.1.) in Switzerland, J. Geophys. Res., 106(D17), 20413-20428, 2001.

Seinfeld, J. H. and Pandis, S. N.: Atmospheric chemistry and physics: from air pollution to climate change. WileyInterscience, 1326 pp., New York, USA, 1998.

Simmonds, P., Manning, A., Derwent, R., Ciais, P., Ramonet, M., Kazan, V., and Ryall, D.: A burning question: Can recent growth rate anomalies in the greenhouse gases be attributed to largescale biomass burning events?, Atmos. Environ., 39, 2513-2517, doi:10.1016/j.atmosenv. 2005.02.018, 2005.

Simoneit, B. R. T.: Biomass burning - a review of organic tracers for smoke from incomplete combustion, Appl. Geochem., 17, 129-162, 2002.

Solomon, S., Qin, D., Manning, M., Alley, R. B., Berntsen, T., Bindoff, N. L., Chen, Z., Chidthaisong, A., Gregory, J. M., Hegerl, G. C., Heimann, M., Hewitson, B., Hoskins, B. J., Joos, F., Jouzel, J., Kattsov, V., Lohmann, U., Matsuno, T., Molina, M., Nicholls, N., Overpeck, J., Raga, G., Ramaswamy, V., Ren, J., Rusticucci, M., Somerville, R., Stocker, T. F., Whetton, P., Wood R. A., and Wratt, D.:: Technical Summary, in Climate Change 2007: The Physical Science Basis. Contribution of Working Group I to the Fourth Assessment Report of the Intergovernmental Panel on Climate Change, edited by: Solomon, S., Qin D., Manning M., Chen Z., Marquis, M., Averyt K. B., Tignor, M., and Miller, H. L., Cambridge University Press, Cambridge, United Kingdom and New York, NY, USA, 2007.

Stohl, A., Wotawa, G., Seibert, P., and Kromp-Kolb, H.: Interpolation errors in wind field as a function of spatial and temporal resolution and their impact on different types of kinematic trajectories, J. Appl. Meteor., 34, 2149-2165, 1995.

Stohl, A., Andrews, E., Burkhart, J. F., et al.: Pan-Arctic enhancements of light absorbing aerosol concentrations due to North American boreal forest fires during summer 2004, J. Geophys. Res., 111, D22214, doi:10.1029/2006JD007216, 2006.

Tanimoto, H., Kajii, Y., Hirokawa, J., Akimoto, H., and Minko, N. P.: The atmospheric impact of boreal forest fires in far eastern Siberia on the seasonal variation of carbon monoxide: Observations at Rishiri, a northern remote island in Japan, Geophys. Res. Lett., 27(24), 4073-4076, 2000.

Tressol, M., Ordonez, C., Zbinden, R., Brioude, J., Thouret, V., Mari, C., Nedelec, P., Cammas, J.-P., Smit, H., Patz, H.-W., and Volz-Thomas, A.: Air pollution during the 2003 European heat wave as seen by MOZAIC airliners, Atmos. Chem. Phys., 8, 2133-2150, 2008, http://www.atmos-chem-phys.net/8/2133/2008/.

Turquety, S., Coheur, P.F., Hurtmans, D., Clerbaux, C., Szopa, S., 
Cozic, A., Ravetta, F., Real, E., Tsamalis, C., and Pelon, J.: Analysis of pollution transport from forest fires in the Mediterranean during the summer 2007, Geophys. Res. Abstr., 10, EGU2008A-08055, 2008.

Val Martñ, M., Honrath, R. E., Owen, R. C., Pfister, G., Fialho, P., and Barata, F.: Significant enhancements of nitrogen oxides, black carbon, and ozone in the North Atlantic lower free troposphere resulting from North American boreal wildfires, J. Geophys. Res., 111, D23S60, doi:10.1029/2006JD007530, 2006.

van der Werf, G. R., Randerson, J. T., Giglio, L., Collatz, G. J., Kasibhatla, P. S., and Arellano, A. F.: Interannual variability in global biomass burning emissions from 1997 to 2004, Atmos. Chem. Phys., 6, 3423-3441, 2006,

http://www.atmos-chem-phys.net/6/3423/2006/.

Van Dingenen R., Putaud J. P., Martins-Dos Santos S., and Raes F.: Physical aerosol properties and their relation to air mass origin at Monte Cimone (Italy) during the first MINATROC campaign, Atmos. Chem. Phys., 5, 2203-2226, 2005,

http://www.atmos-chem-phys.net/5/2203/2005/.

Vergeiner, I. and Dreiseitl, E.: Valley winds and slope windsObservations and elementary thoughts, Meteorol. Atmos. Phys., 36, 264-286, 1987.

Volz-Thomas, A., Beekmann, M., Derwent, D., Law, K., Lindskog, A., Prevot, A., Roemer, M., Schultz, M., Schurath, U., Solberg S., and Stohl, A.: Tropospheric Ozone and its Control in: Towards Cleaner Air for Europe - Science, Tools and Applications. Part 1: Results from the EUROTRAC-2; Synthesis and Integration (S\&I) Project, edited by: Builtjes, P. J.-H., Harrison, R. M., Midgley, P. M., and Tørsen, K., International Scientific Secretariat, Munchen, Germany, 73-122, 2002.

Wang, T., Wong, H. L. A., Tang, J., Ding, A., Wu, W. S., and Zhang, X. C.: On the origin of surface ozone and reactive nitrogen observed at a remote mountain site in the northeastern Qinghai-Tibetan Plateau, western China, J. Geophys. Res., 111(D8), D08303, doi:10.1029/2005JD006527, 2006.

Weiss-Penzias, P., Jaffe, D. A., Swartzendruber, P., Dennison, J. B., Chand, D., Hafner, W., and Prestbo, E.: Observations of Asian air pollution in the free troposphere at Mount Bachelor Observatory during the spring of 2004, J. Geophys. Res., 111, D10304, doi:10.1029/2005JD006522, 2006.
Westerling, A. L., Hidalgo, H. G., Cayan, D. R., and Swetnam, T. W.: Warming and earlier spring increase western US forest wildfire activity. Science, 313, 940-943, 2006.

Wofsy, S. C., Sachse, S. C., Gregory, G. L., et al.: Atmospheric chemistry in the arctic and subarctic: Influence of natural fires, industrial emissions, and stratospheric inputs, J. Geophys. Res., 97, 16731-16746, 1992.

Wotawa, G. and Trainer, M.: The influence of Canadian forest fires on pollutant concentrations in the United States, Science, 288(5464), 324-328, 2000.

Wotawa, G., Kroger, H., and Stohl, A.: Transport towards the Alps - results from trajectory analyses and photochemical model studies, Atmos. Environ., 34, 1367-1377, 2000.

World Meteorological Organization (WMO): Global Atmospheric Watch measurement guide, Tech. Doc. 1073, GAW Rep. 143, Geneva, Switzerland, 2002.

World Meteorological Organization (WMO): Annual Bulletin on the Climate in WMO Region VI - Europe and Middle East. Deutscher Wetterdienst, Offenbach am Main, Germany, 2007.

Yokelson, R. J., Bertschi, I. T., Christian, T. J., Hobbs, P. V., Ward, D. E., and Hao, W. M.: Trace gas measurements in nascent, aged, and cloud processed smoke from African savanna fires by airborne Fourier transform infrared spectroscopy (AFTIR), J. Geophys. Res., 108(D13), 8478, doi:10.1029/2002JD002322, 2003.

Zaveri, R. A., Saylor, R. D., Peters, L. K., McNider, R., and Song, A.: A model investigation of summertime diurnal ozone behaviour in rural mountainous locations, Atmos. Environm., 29, 1043-1065, 1995.

Zellweger, C., Ammann, M., Buchmann, B., Hofer, P., Lugauer, M., Ruettimann, R., Streit, N., Weingartner, E., and Baltensperger, U.: Summertime $\mathrm{NO}_{\mathrm{y}}$ speciation at the Jungfraujoch, $3580 \mathrm{~m}$ above sea level, Switzerland, J. Geophys. Res., 105(D5), 66556667, 2000.

Zhang, Y., Sunwoo, Y., Kotamarthi, V., and Carmichael, G. R.: Photochemical oxidant pro-processes in the presence of dust: An evaluation of the impact of dust on particulate nitrate and processes ozone formation, J. App. Met., 33, 813-824, 1994.

Zhang, Y., Carmichael, G. R.: The role of mineral aerosol in tropospheric chemistry in East Asia-a model study, J. Appl. Met., 38, 353-366, 1999. 